\title{
EL MEDIO NATURAL EN LA VERTIENTE MERIDIONAL DEL TAJO EXTREMEÑO EN LA BAJA EDAD MEDIA ${ }^{\prime}$
}

\author{
JuLián ClEMENTE RAMOS \\ Universidad de Extremadura
}

\begin{abstract}
SUMARIO
1. Introducción.- 2. Población, recursos y medio natural.- 3. La vegetación natural: 3.1. El punto de partida.- 3.2. El bosque ideal: un monte hueco de encinas.- 3.3. Panorámica general.- 3.4. Las especies vegetales: el predominio de las quercíneas.- 3.5. Formas de degradación: el matorral.- 3.6. La vegetación de ribera.- 4. La fauna: 4.1. Una especie en receso: el oso. 4.2. La lucha contra un depredador: el lobo.- 4.3. Herbívoros y ornitofauna.- 4.4. El medio acuático.- 5. Conclusiones.
\end{abstract}

\section{INTRODUCCIÓN}

El estudio del medio natural por el medievalismo español es claramente insuficiente, tanto en un sentido cuantitativo como metodológico. Todo ello a pesar de que se constate la fuerte influencia que ejerce sobre la actividad humana. En los estudios regionales o comarcales se señala una

\footnotetext{
'Este trabajo ha sido realizado dentro del proyecto "Hombre y medio ambiente en la historia", financiado por la Junta de Extremadura. Las abreviaturas utilizadas son las siguientes: ACP: Archivo de la Catedral de Plasencia; AHN: Archivo Histórico Nacional; AHPC: Archivo Histórico Provincial de Cáceres; AMAL: Archivo Municipal de Arroyo de la Luz; AMC: Archivo Municipal de Cáceres; AMP: Archivo Municipal de Plasencia; AMT: Archivo Municipal de Trujillo.

"Anuario de Estudios Medievales", 3(0/1 (2(0)(0))
} 
serie de generalidades sobre las especies arbóreas y la abundancia o escasez de caza.

Pretendemos en el presente trabajo abordar el estudio del medio natural en un espacio y un tiempo determinados. Vamos a partir del concepto de ecosistema en cuanto engloba vegetación y fauna. La explotación y aprovechamientos humanos del medio natural no nos interesan más que como condicionantes generales sobre las especies vegetales y animales. La actividad humana juega un papel central debido a su capacidad para deforestar y cazar. De este modo, el hombre se configura como el gran protagonista para explicar el estado del medio natural. El estudio se inscribe en unas coordenadas espaciales y temporales específicas. Sobre las primeras, hemos abordado una unidad física que viene delimitada por el Tajo al norte, la divisoria de aguas Tajo-Guadiana al sur, Portugal al oeste y el concejo de Talavera de la Reina al este. Estamos ante un espacio físico que presenta, con diversas variantes, una relativa homogeneidad. Esta homogeneidad va a generar un ecosistema dominante en el periodo bajomedieval, el espacio adehesado, que va a definirse por su mayor o menor degradación en las distintas comarcas que lo conforman. Hemos optado, por tanto, tratándose de un estudio del medio natural, por una unidad con personalidad geográfica antes que por una unidad jurisdiccional.

El espacio que hemos elegido presenta unas características físicas precisas. En primer lugar, los suelos se van a caracterizar por ser poco evolucionados y predominantemente ácidos ${ }^{2}$. Los ríos (Tajo, Almonte, Salor) discurren encajonados durante gran parte de su recorrido; por ello, los riberos se han convertido en espacios inhóspitos y de escasas potencialidades económicas. Sólo en algunos lugares se han originado suelos evolucionados y suficientemente profundos. El componente edáfico va a impedir un importante desarrollo agrario. Sin duda, esto explica que esta zona no llegue a albergar en la época medieval una elevada población, lo que es debido no tanto a su dedicación ganadera como a las condiciones físicas. Las precipitaciones alcanzan en la penillanura, salvo excepciones como Cáceres y Brozas, los $500 \mathrm{~mm}$., llegando en ocasiones, merced a la influencia atlántica, más perceptible en el oeste, a rebasar los $600 \mathrm{~mm}$. Sin embargo son las estribaciones montañosas situadas al sur, que marcan la divisoria de aguas

\footnotetext{
2Cf. A. García, J. Forteza y col., Suelos de la provincia de Cáceres, Salamanca, 1970; J.F. GAllardo y Mĩ. GONZÁlEZ, Suelos de Extremadura, "Revista de Extremadura", 8 (Mayo-Agosto 1992), pp. 5-27.
} 
con el Guadiana, y al este las que aumentan sensiblemente la pluviosidad. Desde la Sierra de Montánchez hacia el oeste, continuando por la de las Villuercas y sus prolongaciones montañosas hacia el Tajo, las precipitaciones superan los $700 \mathrm{~mm}$., llegando a $1.034 \mathrm{~mm}$. en Berzocana. En la zona occidental, las moderadas alturas de la Sierra de San Pedro, (500-700 metros) tienen una influencia menos marcada ${ }^{3}$.

La vegetación que se desarrolla en esta zona es la de tipo mediterráneo de encinas (Quercus rotundifolia), alcornoques (Quercus Suber) y rebollos (Quercus Pirenaica), y sus especies asociadas y formas de degradación de retamares, piornales, brezales y jarales ${ }^{4}$.

En cuanto a las coordenadas temporales, la relación hombre/medio natural conoce diversas etapas a lo largo de la Edad Media. Si la Alta Edad Media es la etapa del gran predominio del inculto y de la fauna salvaje $\mathrm{e}^{5}$, y el periodo de las grandes roturaciones, el de una paulatina deforestación ${ }^{6}$, la Baja Edad Media se caracteriza por la necesidad de limitar los aprovechamientos silvícolas y la caza, como único medio de posibilitar el abastecimiento, en primer lugar, de leña y madera, y, subsidiariamente, de caza y pesca. En la corona de Castilla en general y en Extremadura en particular, los indicios sobre la escasez relativa de bosques y las normas restrictivas en la explotación de la vegetación arbórea y de la fauna salvaje se generalizan conforme avanza el siglo $\mathrm{XV}^{7}$. A finales de este siglo, caracterizado por un

\footnotetext{
${ }^{3}$ E. Martínez de PISÓN (dir.), Paisajes naturales de Segovia, Avila, Toledo y Cáceres, Madrid, 1977 pp. 191 y 196-7; Caracterización agroclimática de la provincia de Cáceres. Madrid, 1986, pp. 111 y $122-9$.

${ }^{4}$ E. Martínez de Pisón, Ibid., pp. 191-192 y 198.

${ }^{5} \mathrm{M}$. MONTANARI, L'alimentazione contadina nell'alto medioevo, Napoles, 1979, pp. 34-49 y 254-306; L'ambiente vegetale nell'alto medioevo. Spoleto, 1990 ("Settimane di Studio", XXXVII); L.A. GARCÍA MORENO, El paisaje rural y algunos problemas ganaderos en España durante la antigüedad tardía (s. V-VII), "Estudios en Homenaje a Don Claudio Sánchez Albornoz en sus 90 años", I, Buenos Aires, 1983, pp. 401-26; $\mathrm{M}^{\mathrm{a}}$ del C. PALlarÉS MÉNDEZ, El monasterio de Sobrado: un ejemplo del protagonismo monástico en la Galicia medieval, La Coruña, 1979, pp. 47-50.

'G. DuBY, Economia rural y vida campesina en el occidente medieval. Barcelona, 1968, pp. 93-121; M. DuRANY, La región del Bierzo en los siglos centrales de la Edad Media, 10701250, La Coruña, 1989, pp. 106-140; E. PorTEla Silva, La región del obispado de Tuy en los siglos XII a XV. Una sociedad en la expansión y en la crisis, Santiago, 1976, pp. 163-8.

${ }^{7}$ Cf. nota 182; E. PASTOR DíAZ DE GARAYO, Salvatierra y la Llanada oriental alavesa (Siglos XIII-XV), Vitoria, 1986, pp. 83-4; I. TORRENTE FERNÁNDEZ, El dominio del monasterio de San Bartolome de Nava (siglos XIII-XVI), Oviedo, 1982, p. 98; F. RUIZ GómEZ, Las aldeas castellana en la Edad Media. Oña en los siglos XIV y XV. Madrid, 1990, p. 167. Es una realidad general en Europa: M. DEVEZE, Forêt françaises y forêt allemandes. Etude historique
} 
fuerte crecimiento, se entra en una fase en la relación hombre/medio natural que se mantendrá en líneas generales durante toda la Edad Moderna y que contrasta fuertemente con fases anteriores de la Edad Media.

Nuestro estudio intentará fundamentalmente abordar, dentro de un espacio delimitado, las repercusiones y adaptaciones que la coyuntura alcista del siglo XV ha producido en la explotación de las riquezas naturales y su estado de conservación.

\section{POBLACIÓN, RECURSOS Y MEDIO NATURAL}

Los mecanismos de desarrollo rural de la sociedad medieval tienen un carácter marcadamente extensivo. Espacio agrario y población mantienen una estrecha relación. Así sucede con las grandes roturaciones plenomedievales e, igualmente, con la problemática agraria bajomedieval. En Extremadura, merced a una tardía conquista cristiana, la población se mantuvo en uno niveles moderados y sólo muy avanzada la primera mitad del siglo XIV empezó a tener una cierta densidad. Quizás debido a esta nueva situación se documentan problemas entre Valencia de Alcántara y algunas de sus aldeas que tienen un perfil muy similar a los que aparecen a finales del siglo $\mathrm{XV}$ y principios del XVI. Los vecinos de Esparragal "acotaban sus prados y egidos sin licencia ni consentimiento suyo y de su procurador. Impedianles también el pasto de las viñas y que cortasen madera para sus casas y labores, que cazasen en sus montes, pescar en sus pesqueras"; en el conflicto con Herrera, el maestre Nuño Chamizo manifiesta su deseo de que "guardasen los unos y los otros la buena vecindad que habían tenido en tiempo de los maestres sus antecesores" ${ }^{8}$. Se trata en todo caso de conflictos puntuales que están lejos de definir una realidad generalizada.

En cualquier caso, la crisis bajomedieval ${ }^{9}$ y el consiguiente descenso

comparée, "Revue Historique", CCXXXVI (1966), pp. 51-3; este autor considera difícil el equilibrio silvo-pastoril en un "monde plein" (L'equilibre agro-sylvo-pastoral du XIII au XVIII siècle en Europe movenne et Europe méridionale, "Agricoltura e trasformazione dell'ambiente. Secoli XIII-XVIII", Florencia, 1984 -"XI Settimana di Studio, Prato"-, p. 335)

${ }^{8}$ A. DE Torres y TAPIA, Cronica de la Orden de Alcántara, Madrid, 1763, vol. II, p. 41.

"Los fenómenos epidémicos y los despoblados forman parte del paisaje extremeño en las décadas que siguen a 1349: C. FERNÁNDEZ-DAZA ALVEAR, El señorio de Burguillos en la Baja Edad Media extremeña, Badajoz, 1981, p. 56; J. SOlano DE FIgUEROA, Historia eclesiástica de la ciudad y obispado de Badajoz, Badajoz, 1929. III, p. 311; M“' C. GERBET, La noblesse 
poblacional van a producir la desaparición temporal de estos problemas, que sólo proliferarán con la coyuntura agraria y demográfica alcista del XV. A lo largo de este siglo se documenta un claro incremento de la población que va a situar a Extremadura dentro de unos niveles demográficos medios en el contexto de la corona de Castilla ${ }^{10}$. Los inicios de este proceso se documentan en la tercera década del siglo. A falta de datos demográficos directos, diversos indicios nos informan del cambio de coyuntura. En la zona de Alcántara parece detectarse una escasez de bosques, lo que hay que interpretar no tanto como una disminución del espacio arbolado sino como un incremento de las necesidades ante el aumento de la población. En 1425, la villa de Alcántara obtiene el derecho de "cortar madera para sus casas, labor, haceñas y molinos en los montes de todas las encomiendas"; en 1436, Brozas solicita "poder cortar toda la madera de que necesitasen para sus casas y labor en el monte de la dehesa de Araya y en los demás de la orden" ". Estos problemas, inicialmente parece que muy localizados, están relacionados con un crecimiento de la población que se manifiesta en un incremento del espacio agrario. No de otro modo puede entenderse que San Vicente de Alcántara pida que se le asigne una dehesa boyal en 1429; en 1428 , aparece como una realidad bastante difundida la realización de "roças para pan" en el termino de Trujillo; en 1434 se nos dice que "en el berrocal e en los exidos e terminos de las aldeas e lugares de la dicha çibdat e en los terminos desta çibdat tomavan muchas tierras e logares asy para fazer casas e viñas e huertas e huertos e alcaçeres e molinos mas de los que era razón e derecho e en aquellos lugares que se non devian tomar" ${ }^{12}$.

El crecimiento de la población, y como consecuencia de ello del espacio agrario, se documenta a lo largo de todo el siglo y no hace sino continuar en la centuria siguiente. No está dentro de nuestro interés delimitar

dans la Rovaume de Castille. Etude sur ses structures sociales en Extrémadure de 1454 a 1516, Paris. 1979, pp. 479-80.

${ }^{10} \mathrm{La}$ corona de Castilla tendría en torno a 1492 una densidad ligeramente superior a los 11 habs. $/ \mathrm{km}^{2}$; Extremadura hacia 1530 se acercaría a 10 habs. $/ \mathrm{km}^{2}$ (M.A. LADERO QUESADA, España en 1492, Madrid, 1978, pp. 29 y 31). Ma C. GERBET, Ibid., pp. 57-59, defiende una densidad para Extremadura claramente inferior a la del reino castellano.

"A. DE TORRES Y TAPIA, Ibíd., II, pp. 255, 307 y 262; muy cerca de estos lugares, pero ya en el valle del Guadiana, se documenta el acuerdo entre la villa de Alburquerque y los comendadores de Piedrabuena y Mayorga después de las "pesadas diferencias sobre los pastos y sobre las penas que unos a otros se llevaban quando prendaban sus ganados".

12A. DE TORRES Y TAPIA, Ibíd., II, p. 262; Ma A. SÁNCIIEZ RubIO, Documentación medieval. Archivo Municipal de Trujillo, Cáceres, 1992-5, III, pp. 108-109 y 181. 
sus fases, sino hacer un balance de la realidad demografica hacia 1500 . Nuestra intención es contestar a los interrogantes que puedan plantearse sobre el nivel de la población como elemento central para entender la problemática del medio natural. La densidad demográfica sería más elevada a finales del siglo XV que a mediados del XIV. La inexistencia en esta época, al menos de modo general, de la problemática que se desarrolla posteriormente parece un elemento de peso para sostener esta afirmación. En cualquier caso, la población de principios del siglo XVI está lejos de representar un máximo demográfico. Continuará creciendo a la largo del siglo y aún alcanzará cotas más elevadas en el XVIII. La población de la provincia de Cáceres crece entre 1574 y 1800 un $24,3 \%$. Dentro de nuestro ámbito geográfico, si comparamos datos de finales del XV, comienzos del XVI o del censo de 1528-32 (generalmente correspondientes a vecinos pecheros) con los ofrecidos por los censos de Ensenada (1752; sólo computamos los pecheros vecinos útiles y pecheros jornaleros) o Floridablanca (1787), podemos apreciar como a lo largo de la época moderna la población se incrementó considerablemente en la Tierra de Cáceres (unos dos mil vecinos en 1479, casi cuatro mil en 1752 y cerca de dieciseis mil habitantes en 1787), la jurisdicción alcantarina (unos tres mil vecinos en 1532, más de cuatro mil seiscientos en 1752 y casi veinticinco mil habitantes en 1787) o la santiaguista (mil quinientos vecinos en 1501, más de dos mil setecientos en 1752 y más de doce mil habitantes en 1787); creció moderadamente en la tierra de Trujillo (algo más de dos mil vecinos en 1531-2 y de dos mil quinientos en 1752, menos de diez mil habitantes en 1787); y se mantuvo o disminuyó en la antigua jurisdicción placentina (las lugares situados al sur del Tajo contaban con algo más de mil cuatrocientos vecinos en 1494 y de mil quinientos en 1752; no llegan a los cuatro mil quinientos habitantes en 1787$)^{13}$.

\footnotetext{
${ }^{13}$ A. Rodríguez Sánciez, M. Rodríguez Cancilo y J. Fernández Nieva, Historia de Extremadura. III. Los tiempos modernos, Badajoz, 1985, pp. 484-90; E. LLOPIS AGELAN, M.A. Melón, M. Rodríguez Cancho, A. Rodríguez Grajera y F. ZaRandieta, El movimiento de la población extremeña durante el Antiguo Regimen, "Revista de Historia Económica", VIII (1990), $\mathrm{n}^{\circ}$ 2, p. 445; E. CABRERA y G. LORA, Datos sobre la población y la configuración jurisdiccional de Extremadura en el tránsito de la Edad Media a la Moderna, "Ifigea", I (1984), pp. 71-5; Ma D. GARCía OlIVA, Organización económica y social del concejo de Cáceres y su tierra en la Baja Edad Media, Cáceres, 1990, pp. 61-3; E.C. DE SANTOS CANALEJO, La historia medieval de Plasencia y su entorno geo-histórico: la Sierra de Béjar y la Sierra de Gredos, Cáceres, 1986, pp. 101 y 103-4; D. Rodríguez BLANCO, La Orden de Santiago en Extremadura (siglos XIV y XV), Badajoz, 1985, p. 98; Censo de población de la Corona de Castilla "Marques de la Ensenada", 1752, I, Madrid, 1991, pp. 191-7; Censo de 1787
} 
El crecimiento de la población ha tenido una influencia clara en la estructura de la producción. Conforme se desarrolla el ascenso demográfico, aparecen alusiones a la roturación de tierras. Esto va a ocasionar una agrarización del paisaje y la economía rurales. Si bien este proceso en las primeras décadas del siglo XV debió ser de una intensidad limitada, conforme avanzamos hacia el final del siglo tuvo que adquirir una fuerza creciente. En la última década hay indicios que denotan una cierta escasez de tierras, lo que quizás no haya que generalizar. Los vecinos de Brozas realizan apropiaciones en la cañada real en 1496 y $1497^{14}$. En un conflicto entre Trujillo y sus aldeas en 1487 se señala que "los dichos conçejos e vezinos dellos estavan perdidos e fatigados a causa de non tener tierras en que labrar e senbrar, porque los dichos logares se han fecho de poco aca muy copiosos e mas poblados de lo que solian ser e la tierra e termino dellos no se a creçentado... de manera que por falta de tierras en que labrar se despoblaran"15. En Cáceres, la ocupación ilegal de tierras que realizan miembros de la oligarquía local ocasiona que "los vezinos... no tienen donde apaçentar su ganados ni roçar ni cortar”. Más sintomático aún, por no tratarse de una apreciación general sino de un hecho concreto, es que, entre finales del XV y principios del XVI, las tierras de las dehesas de Zafra y Zafrilla pasen a cultivarse cada cuatro años, en vez de cada cinco, como se había hecho hasta entonces ${ }^{16}$. Los vecinos de Almoharín aparecen en 1480 ocupando tierras comunes y concejiles y transmitiéndolas como propias ${ }^{17}$.

El hambre de tierras lleva a poner en cultivos incluso tierras de mala calidad. En 1496 hasta las tierras "fragosas" aparecen como objeto de roturación en Berzocana; en las Ordenanzas de la Sierra de San Pedro, del mismo año, se prohíbe que nadie pueda labrar en "canpo raso en que puedan pastar ganados, porque aquello sea para pastos de los dichos ganados", sin embargo, si se permite la roturación "de los xarales adentro, en lo aspero e bravo de los montes" ${ }^{18}$. La contradicción ganadería/agricultura aparece

\footnotetext{
"Floridablanca". Cáceres, Madrid, 1987, pp. 1167-71

${ }^{14} \mathrm{AHN}$, Mesta, caja 19, n 3, 4, 5 y 6.

${ }^{15} \mathrm{M}^{\mathrm{a}} \mathrm{A}$. SÁnchez RuBIo, El concejo de Trujillo en el tránsito de la Edad Media a la Moderna, Badajoz, 1993, pp. 56-7.

${ }^{16} \mathrm{M}^{\mathrm{a}} \mathrm{D}$. García Oliva, Documentación histórica del Archivo Municipal de Cáceres, Cáceres, 1988, doc. 7.

${ }^{17}$ D. RodríGuez Blanco, Ibíd., pp. 229-34.

${ }^{18}$ SÁncilez Rubio, Documentación, I, doc. 136; García Oliva, Documentación, doc. 134.
} 
ahora, al margen de su componente social, como una manifestación más de la presión sobre los recursos.

En este contexto, las dehesas boyales se convierten en una necesidad ineludible y empiezan a proliferar y a necesitar de una protección especial $^{19}$. Su mismo desarrollo muestra por un lado el incremento de la producción agraria y el carácter cada vez más limitado del espacio disponible.

Las transformaciones que produce el desarrollo de las roturaciones y la agrarización del mundo rural tiene unas importantes consecuencia en el medio natural, sujeto a una presión creciente. Pasado un cierto umbral poblacional, y dada la absoluta necesidad que tiene esta sociedad de integrar los aprovechamientos agrarios, pecuarios y silvícolas, resulta inevitable el control y la protección del bosque, la caza y la pesca. En la primera mitad del siglo XV, cuando empieza a adquirir fuerza el proceso que hemos definido, aún se seguiría con unas normativas y una permisividad incompatibles con la nueva situación. El concejo de Trujillo cambia ordenanzas y estatutos que considera "desaguisadas" porque "las monedas y los montes y aun las condiçiones de los onbres e la calidad de los negoçios no son agora de la calidad que heran al tienpo que las dichas hordenanças se fizieron" ${ }^{20}$. Las ordenanzas municipales, que proliferan en la Baja Edad Media, especialmente a partir de 1450 , vienen a responder a la problemática específica de los diversos concejos. Llamativamente, este intento de responder a condiciones particulares no impide que tengan una gran homogenidad en los campos abordados y en las soluciones propuestas. No podía ser de otro modo, pues las distintas villas se enfrentan a circunstancias similares derivadas del crecimiento poblacional y del riesgo de desaparición de sus bosques. Todas las ordenanzas dedican un tratamiento pormenorizado al monte. Se concreta su forma de explotación para la actividad ganadera y la obtención. de leña y madera

Diversos indicios nos inclinan a pensar en la escasez relativa de arbolado, que produce conflictos y desarreglos. El pleito que en 1492 enfrenta en Cáceres a las autoridades municipales con el común de la villa

\footnotetext{
${ }^{19}$ A. DE TORRES Y TAPIA, Ibíd., II, p. 262; AHN, Mesta, caja 176, no 10; Ma A. SÁNCHEZ RUBIO, El concejo de Trujillo, p. 334.

2"SÁnCIIEZ Rubio, Documentación, II, p. 22.
} 
y tierra ${ }^{21}$ ofrece una doble lectura. En estas fechas se está desarrollando un uso muy restrictivo del bosque, lo que explica la necesidad de obtener licencias previas para el corte de leña o madera. El común considera que las licencias sólo se conceden a personas afectas a la oligarquía municipal, debiendo los demas comprar la leña en lugares comarcanos. Las autoridades municipales responden que no hay ningún interés particular en la protección de los montes, sino el deseo de que "se cortasen moderadamente e que no se talasen ni destruyesen". En momentos de escasez, los productos del bosque adquieren un valor superior y su control puede ser económicamente muy lucrativo. Es normal que en estas condiciones se recrudezca la lucha por su gestión. En los años anteriores a 1509, la ausencia de control suficiente en la recolección de la bellota ocasiona en Trujillo que algunos no hallan podido cogerla; en 1521, en un conflicto con la Mesta, el concejo arguye en relación con las derechos de esta hermandad ganadera que "si se diese lugar que las partes contrarias pudiesen ramonear en los montes del termino de ella se talarian e destruirian" ${ }^{22}$.

El ejemplo más claro y unívoco lo ofrece sin duda Alcántara. Como en otros casos, aparece en un conflicto entre esta villa y la Mesta. Mientras la villa defiende la escasez de su arbolado, la organización ganadera hace lo mismo con sus derechos. Es la misma Mesta la que confirma las afirmaciones de Alcántara cuando dice que "las dichas hordenanças de la dicha villa los dichos sus partes ni los dichos sus pastores no las podian guardar porque en muchas partes de los dichos terminos no avia monte que se avastase para haser puentes sy no dexasen horca e aljuma"23.

En cualquier caso, la escasez hay que entenderla en un sentido relativo. Estamos ante espacios que albergan aún mucho bosque, pero no debemos olvidar las multiples necesidades que satisface (calefacción, construcción, sostenimiento de la ganadería, etc.). La escasez aparece en una sociedad tradicional cuando el espacio arbolado podría ser definido aún dentro de parámetros actuales como relativamente abundante. Más que de escasez debemos hablar de la necesidad de gestionar más cuidadosa y racionalmente el bosque al haber disminuido drásticamente respecto de fases

\footnotetext{
${ }^{21}$ García Oliva, Documentación, doc. 91.

22" "los años pasado a avido mucho desorden en el coger de la bellota, porque algunas personas la an cogido sin ser desacotada e otros no an cogido ninguna" (SÁNCHEZ RUBIO, Documentación, II, doc. 308); AHN, Mesta, caja 212, nº 19

${ }^{23} \mathrm{AHN}$, Mesta, caja, 8, $\mathrm{n}^{\mathrm{O}} 12$.
} 
anteriores ${ }^{24}$. La ausencia de una escasez generalizada se manifiesta en que las nuevas normativas y hábitos que se desarrollan parten normalmente de iniciativas concejiles, que a veces chocan con la justicia real, remisa a asumirlas totalmente, pero obligada a aceptarlas siquiera de modo parcial, y no de normativas generales, no del todo ausentes ${ }^{25}$.

La presión sobre los recursos y la necesidad de compaginar los diversos aprovechamientos, igualmente necesarios e imprescindibles, conlleva cambios que en torno al mil quinientos parecen recientes. Por un lado, se intenta el aprovechamiento del estrato arbustivo para rebajar la presión sobre el estrato arbóreo. En Cáceres se dispone en 1494 que para cocer la cal no se utilice leña de alcornoque salvo para "enhornar o çevar los hornos", debiendo utilizarse "la lenna de escoba, e xara e lantisca e otras lennas" 26 . En Valencia de Alcántara, la creciente utilización del matorral se manifiesta en su apropiación individual ${ }^{27}$. Este cambio de actitud con respecto al matorral y la necesidad de desarrollar una actitud más conservacionista aparece con gran nitidez en la provisión real en la que los Reyes Católicos disponen sobre el aprovechamiento de la coscoja (Quercus coccifera). Especie que no pasa de arbusto en nuestro territorio, es una manifestación de la degradación del paisaje natural, adaptándose bien a zonas deforestadas en donde la mayor evaporación favorece a especies con menores exigencias hídricas. Este arbusto produce la grana, de gran interés para el sector textil. Esto explica la protección que se le dispensa y la necesidad de

\footnotetext{
${ }^{24} \mathrm{La}$ villa de Alcántara señalaba en 1512 , tras sostener la escasez de montes en el término, que respetándose las ordenanzas "se conservavan los montes ... avia leña abasto para los besinos de la dicha villa e su tierra e para las partes contrarias e sus pastores" (AHN, Mesta, caja, 8 , $\left.\mathrm{n}^{\circ} 12\right)$.

${ }^{25}$ E. Bauer MANDERSCheid, Los montes de España en la historia, Madrid, 1980, pp. 54-5.

2"García Oliva, Documentación, doc. 122, p. 214; esta utilización del matorral debió alcanzar un gran desarrollo: en 1516 o poco antes, unos vecinos de Brozas "hallaron çiertos vezinos de Arroyo del Puerco haziendo leña de xara dentro del dicho termino" (AMAL, leg. $625, n^{\circ} 1$, fol. $72 \mathrm{v}$ ).

${ }^{27}$ Nadie puede "llevar de los barbechos ajenos la escoba ni retama ni otros montes que en ellos tienen sus dueños roçados... en las mesmas penas, cayan los que cortaren y roçaren las dichas escobas y retamas de los dichos barvechos ajenos, como los que las sacaren y llevaren como dicho es" (D. BoHóRQuez JimÉnEZ, Ordenanzas de Valencia de Alcántara, Cáceres, 1982, pp. 98-9).
} 
limitar su tala o la utilización de su madera en los hornos ${ }^{28}$. Disfruta, de este modo, de una atención sólo dispensada a las quercíneas arbóreas.

La nueva situación va a producir la necesidad de incrementar la protección del bosque. Se actuará en dos campos: por un lado, se van a incrementar las penas pecuniarias; por otro, se cambiarán las normativas vigentes.

Las nuevas penas no pueden explicarse sólo por la pérdida de poder adquisitivo del dinero ${ }^{29}$. Su gran incremento tiene como finalidad aumentar su carácter disuasorio. En este sentido es sintomático la resolución del conflicto que opone a Trujillo y a la Mesta en la primera década del XVI. Doña Juana falla a favor de la permanencia de las penas antiguas pues "la dicha çibdad no ha mostrado ni paresçe sufiçiente titulo por donde puede se hazer el dicho acreçentamiento de la dicha pena", pero finalmente admite una posición intermedia entre la costumbre antigua y la nueva normativa de las ordenanzas, situándose la pena en doscientos maravedís. Sin duda, las penas antiguas son ya poco disuasorias posiblemente debido a una doble casuística: la perdida de valor de la moneda y la presión creciente que ejerce sobre el bosque una población en aumento ${ }^{30}$.

Las penas sufren una subida muy importante entre las últimas décadas del siglo XV y las primeras de la centuria siguiente. Hacia 1480 y 1490 , la pena por cortar un arbol era de cien maravedís. Esta es la cantidad que aparece en las ordenanzas de Alcántara y en los acuerdos vecinales suscritos por Cáceres con Montánchez y Trujillo ${ }^{31}$. En la última década del XV, aumentan sensiblemente. En 1490, en el nuevo acuerdo entre Cáceres

\footnotetext{
28."muchas personas cortan la dicha coscoja para fornos e para otras cosas, e que asy mismo al tienpo que la dicha grana se coje las personas que la cojen cortan la rama e otros cojen la dicha grana syn sazon... nos fue suplicado... que las coscojas no se saquen ni corten de rayz, e que asy mismo la dicha grana no se coja syn sazón" (GARCía Oliva, Documentación, doc. 199, a. 1501).

${ }^{29}$ Asistimos entre finales del XV y comienzos del XVI a subidas moderadas o intensas de precios, pero en ningún caso comparables a las que sufren las penas establecidas por la tala de arboles: en Trujillo, un cerdo vale diez maravedís en 1485 y 17 en 1509; un carnero, 13 mrs. y 4 cornados en 1485 y 14 mrs en 1509; un par de palomas, 10 mrs. en 1498 y 12 en 1509; un celemín de sal, $12-13$ mrs. en 1498 y 17 en 1509 (SÁNCHEZ RUBIO, El concejo de Trujillo, pp. 419-421); en Cáceres, el par de palomas mantiene prácticamente estable su valor, ocho maravedís, entre 1502 y 1520 (GARCía Oliva, Documentación, doc. 211; AMC, Cuentas de propios de 1520 , fol. $13 \mathrm{r}$ ).

${ }^{30}$ SÁNCIIEZ RUBIO, Documentación, II, 312.

${ }^{31}$ AHN, Mesta, caja 8, no 12; García Oliva, Documentación, doc. 20; SÁnchez Rubio, Documentación. II, 169.
} 
y Montánchez cortar un arbol sigue estando penado con cien maravedís si es para madera, pero si es para leña la pena es de seiscientos; en las Ordenanzas del monte de 1494 , la cantidad se eleva a doscientos maravedís. Las ordenanzas de Valencia de Alcántara establecen una pena de seiscientos maravedís (trescientos para un fresno) ${ }^{32}$. A principios del XVI, la cuantía asciende en Trujillo a doscientos maravedís, para sólo algo más tarde situarse en trescientos y a veces en quinientos o seiscientos según las protestas de la Mesta; en un acuerdo con Montánchez se señala una pena de quinientos maravedís para la encina y de trescientos para el roble y el alcornoque. Seiscientos maravedís es la cantidad vigente en Alcántara por estas mismas fechas. Quizás la escasez explique que en fecha tan temprana como 1485 se establezca una pena de mil maravedís en Alconétar, precisamente en un acuerdo entre esta villa y Cáceres, en donde son muy inferiores. La Mesta debió contribuir a moderar las penas, aunque posiblemente se situarían por encima de las normativas reales, pues en Trujillo en 1513 alcanzan los trescientos maravedís ${ }^{33}$.

En relación con el desarrollo de hábitos más restrictivos en la explotación del bosque como medio de facilitar su conservación, el ejemplo más claro lo ofrecen los conflictos entre los concejos y la Mesta, que en realidad no es sino una manifestación de la imposibilidad de mantener prácticas adaptadas a circunstancias pretéritas. La Mesta había obtenido grandes privilegios que le permitían disponer con cierta libertad de la riqueza forestal de las distintas comunidades. Este derecho, que se hizo confirmar repetidadamente, es lo que ya no es viable. Choca con las nuevas normativas de las ordenanzas bajomedievales que responden a nuevas necesidades y limitaciones. En 1518 la villa de Alcántara conseguirá que la Mesta tenga que respetar las ordenanzas "çerca de la dicha corta de los dichos montes". En 1521, esta organización ganadera también se verá obligada a respetar las ordenanzas relativas al ramoneo del ganado ${ }^{34}$. Quizás en esta dinámica se explique el desarrollo en 1508 de nuevas normativas de poda en el concejo

\footnotetext{
${ }^{32}$ García Oliva, Documentación, 68 y 122; Bolórquez, Ibid., pp. 124 y 128.

${ }^{33} \mathrm{AHN}$, Mesta, cajas $8, \mathrm{n}^{0} 12$, y 216/, $\mathrm{n}^{0}$ 16; García Oliva, Documentación, doc. 51; SÁNCHEZ RuBIO, Documentación, II, doc. 312, y III, pp. 44-45.

${ }^{34} \mathrm{AHN}$, Mesta, cajas 8, no 12 y $212, \mathrm{n}^{\circ} 19$.
} 
de Trujillo. Las normas antiguas son sustituidas por otras que suponen una poda menos enérgica y de más fácil asimilación por el arbol ${ }^{35}$.

\section{LA VEGETACIÓN NATURAL}

\subsection{El punto de partida}

La problemática existente con el bosque a finales de la época medieval es algo nuevo. En general, a lo largo de la Edad Media la vegetación natural era suficientemente abundante y no se planteaban problemas de escasez. De todos modos, el modelo de crecimiento que desarrolla una sociedad tradicional como la medieval debía llevar necesariamente a la reducción de la masa arbórea, tan necesaria por otro lado por sus diversos productos. El desarrollo de una creciente agrarización de la economía rural cada vez que se produce un crecimiento demográfico como medio de subvenir a unas necesidades sociales en aumento plantea la contradicción agricultura-vegetación natural.

Durante el periodo plenomedieval se desarrollan en Extremadura unos comportamientos respecto del bosque que nos muestran una relativa abudancia y un contraste agudo con la situación que reiteradamente aparece reflejada en las ordenanzas bajomedievales. Refuerza la solidez de nuestra información que proceda de fuentes diversas y que presente una gran homogeneidad.

En los fueros, que responden a una realidad general de toda la submeseta sur, el monte, comparado con el tratamiento pormenorizado y conservacionista que le dedican las ordenanzas, es un gran ausente. El de Cáceres simplemente se limita a señalar que nadie corte encina o alcornoque salvo "pora casas o pora aradros o pora cosa que a lavor pertenesca" ${ }^{36}$; en el de Plasencia no aparece ninguna normativa prohibicionista. Un abundante paisaje vegetal tenía que albergar una caza rica que no necesitaría tampoco

\footnotetext{
${ }^{35}$ "no han de dexar forcon e ramas como antes syno que ha de quedar cada arvol conpado de ramas e aconpañado de ramas en manera que de frutos e que desvien las camadas de las enzinas por manera que el pie del arbol ni las ramas de el no reçiban perjuiçio ni daño" (SÁNCHEZ RUBIO, Documentación, III, p. 84).

${ }^{36} \mathrm{P}$. Lumbreras Valiente, Los fueros municipales de Cáceres. Su derecho público, Cáceres, 1974, p. XX, rub. 1.
} 
de especiales limitaciones. En concordancia con esa situación se conceden importantes privilegios ganaderos desde Alfonso $\mathrm{X}$ que nos ilustran de un comportamiento permisivo hacia el bosque. Fijémonos sólo en uno, el concedido por Sancho IV a Jaraicejo en 1289. Los vecinos de este lugar podrán llevar sus ganados por el reino, pudiendo cortar "rama para los ganados, y leña para cocer su pan, y madera para sus puentes y para todas las otras cosas que lo menester hubieren, y que lo corten por pie o como quisieren, en aquella guisa que les mas competiere, y que hagan corteza para curtir su calzado" ${ }^{37}$. No sólo en la documentación real, sino también en la municipal aparecen normativas permisivas. Las dehesas de Zafra y Zafrilla, próximas a Cáceres, eran, a finales del siglo XIII, "dehesas de coger lande todos aquellos que la quisieren coger, asi los de fuera parte, como los de la villa et del termino" 38 . En los umbrales de la Baja Edad Media, la explotación de la riqueza vegetal de los diversos alfoces bien en virtud de privilegios reales o de normativas locales no era un derecho exclusivo de los respectivos vecinos, sino que el control jurídico que los concejos ejercían sobre sus terminos era compatible con unas costumbres poco restrictivas en relación con las formas de explotación del bosque y con las condiciones de acceso de los posibles beneficiarios. Es esta situación la que posibilita que los privilegios reales que siguen al desarrollo de la Mesta no desencadenen una protesta que haga inviable el ejercicio de los derechos concedidos. Cuando la Mesta se enfrente a Trujillo a principios del siglo XVI en defensa de sus derechos, se aludirá a una situación de respeto secular ${ }^{39}$ que remite a una realidad plenamente vigente en las últimas décadas del siglo XIII y durante todo el siglo XIV, pero desaparecida ya desde la segunda mitad del siglo XV.

¿Cómo podemos imaginarnos el paisaje vegetal en la primera mitad del siglo XIV? Esta zona ha estado sujeta a una ocupación secular. Sin embargo, durante el último siglo del dominio musulmán, e incluso antes, no se ha caracterizado por contar con una abundante población. De hecho, desde 1142 y hasta su definitiva conquista por los cristianos se ha convertido

\footnotetext{
${ }^{37}$ J. Benavides Cileca, Prelados placentinos, Plasencia, 1907, apend. p. 111.

${ }^{3 *}$ A.C. Floriano, Documentación histórica del Archivo Municipal de Cáceres, Cáceres, 1987, doc. 10, a. 1280.

${ }^{39}$ SÁnCIIEZ Rubio, Documentación, II, doc. 312.
} 
en una auténtica marca fronteriza ${ }^{40}$. Esto ha condicionado el paisaje que, poco antes de mediados del siglo XIII, se han encontrado los repobladores. Sin duda, el desarrollo de la repoblación desde la conquista cristiana no debió suponer un cambio profundo, algo que sólo se constata desde las primeras décadas del siglo XV. No es nuestra intención estudiar las transformaciones del paisaje vegetal entre los siglos XII y XIV, pero si obtener una foto fija de sus características generales para contraponerla a la realidad bajomedieval. Nos hemos limitado a la utilización de la toponimia que aparece en los documentación que hemos manejado. Creemos que es suficiente para lo que nos hemos propuesto, tener un elemento de contraste con la realidad de la segunda mitad del siglos XV. Esta toponimia en muchos casos debió fijarse en los primeros momentos de la ocupación cristiana y en su mayor parte sería anterior a 1350. Por ello, aunque en algunos casos sólo aparezca algo más tarde, reflejaría a grandes rasgos el paisaje vegetal que se encontraron los repobladores. Este paisaje debió mantenerse en sus líneas generales hasta 1420 .

El paisaje vegetal de este periodo se define por una doble característica: importancia de la vegetación natural y desarrollo de formas de degradación. Jaraicejo nos ofrece un ejemplo muy ilustrativo. En 1288, Alfonso Godínez vende a Pedro Sánchez de la Camara este lugar “con prados, con pastos, con dehesas, con fuentes, con vasallos y con todos sus terminos pertenencias" ; ese mismo año, Sancho IV aprueba la venta señalando que se otorga "con montes, con fuentes, con ríos, con pastos, con entradas y con salidas", fórmula que se repetirá en otros documentos de éstos años. Jaraicejo recibirá privilegios reales porque "es poblado en fuerte tierra por razón de los golfines" 41 . La imagen de una limitada intervención antrópica parece clara. Pero ¿qué significa la palabra montes? Un documento relativo a este lugar nos lo aclara. En 1284 se delimita con motivo de la donación a Gonzalo Godínez: "Y el otro mojon es el rostro de la xara de los hitos. Y en su derecho, el arroyo ayuso, como da en Almont, en la pesquera de don Sebastian. Y el Almont arriba, como da en los casares de Paulos y en la mesa. Y en su derecho de la mesa, como da en el arroyo de la Vid. Y

\footnotetext{
${ }^{40}$ J. Clemente RAmos, La Extremadura musulmana (1142-1248). Organización defensiva y sociedad, "Anuario Estudios Medievales", 24 (1994), pp. 665-73 y 689-90.

${ }^{4}$ "D. SÁNCIIEZ LORO, Ibíd., vol. B, pp. 49, 58 y 59; Albalá, antigua fortaleza musulmana, y por tanto lugar sujeto a una antigua ocupación, se concede en 1302 "con ríos y fuentes y montes y dehesas y prados y pastos" (Ibid., p. 102).
} 
el arroyo ayuso, como da en los casares de Fellechoso... Y dende, en su derecho, como da en la encina sola... como da en el carrascal de la dehesa" ${ }^{42}$. Contrastando toda la información podemos hacernos una idea cabal del paisaje de esta zona. El desarrollo agrario es escaso, pero la ocupación humana empieza a dar unas pasos consistentes merced a la explotacion ganadera. El paisaje se caracteriza por la fuerte presencia de la vegetación natural (la zona se convierte en refugio de golfines) y el importante desarrollo de ciertas formas de degradación. El estrato arbóreo ha sido aclarado y se desarrolla como consecuencia de este ataque al bosque el monte bajo debido al lento crecimiento de las quercíneas. El matorral (jara, helechos) empieza a impregnar la toponimia.

No debemos excluir hasta mediados del siglo XIV la existencia de bosques poco alterados. Quizás aún siguieran existiendo a finales del XV en Valencia de Alcántara, en donde se mencionan bosques bravos o espesos y bravos en oposición a los jarales. El topónimo valvellido aludiría probablemente a esta realidad. Aparece entre Garciaz y Berzocana y en Valencia de Alcántara, donde da nombre a una de las hojas de cultivo. Es posible que el término moheda, documentado tanto en la llanura (Moheda del Ramón, junto a Bolloluengo; la dehesa de Mohedas en la antigua tierra de Plasencia) como en zonas más abruptas (Mohedas, entre Garciaz y Berzocana) no tuviera a veces un significado muy distinto. Frente a su significado actual de monte alto con jaras y maleza, en la Baja Edad Media aparece dotada de un estrato arbóreo diversificado. En cualquier caso, ya antes de mediados del siglo XIV han debido producirse importantes cambios hasta el punto de hacer de estos bosques poco alterados una de las realidades menos respetadas. Documentos algo posteriores a 1350 nos muestran como estos espacios empezaban a ser explotados y transformados ${ }^{43}$.

Lo primero que llama la atención es la práctica ausencia del topónimo encinar. Representando esta especie el clímax vegetal de la mayor

\footnotetext{
${ }^{42}$ D. SÁNCHEZ LORO, Ibíd., vol. B, p. 42; delimitación practicamente idéntica en p. 62, a. 1289

${ }^{43}$ Para la oposición entre bosques bravos/espesos y jarales, BolIÓRQUEZ, Ordenanzas, pp. 93, 128,132 y 234; sobre el significado del término moheda, Ibíd., pp. 125 y 127 . En la delimitación de Agudo y Mohedas aparecen "las çafurdas que disen de Ferrando Blasques Bote" y "val de las çafurdas"; entre la heredad de Valvellido y los montes y dehesa de Robledo o Mohedas se mencionan topónimos como arroyo de las puercas, la jara o villar del alcornoque gordo, que parece delatarnos la transición a un paisaje adehesado; entre la heredad de las Foyas y Mohedas se documenta una "cuesta del alcornocal espeso" (AMT, leg. 1, n⿳ 1, fols. 7 r.-7 v., 12 r. y 14 v., a. 1353).
} 
parte de la vertiente meridional del Tajo, no ayudaría en exceso para la identificación de un espacio concreto. Lo que si aparece es el toponimo carrascal $^{44}$, que alude a su degradación como monte bajo.

En conjunto, la toponimia nos muestra un espacio vegetal caracterizado por la variedad de especies arbóreas. Estamos ante un bosque mediterráneo que, pese a la degradación que haya podido sufrir, se conserva en una situación razonablemente buena. Junto a la encina, la especie de mayor difusión, alcornoques y robles disponen de una situación dominante en espacios de mayor altura y pluviosidad. El topónimo alcornocal aparece en lugares montañosos como el alcornocal de la sierra de Montánchez o entre Garciaz y Berzocana (villarejo de los alcornoques, villar del alcornoque gordo, cuesta del alcornocal espeso). Vemos, sin embargo, una Corchuela en plena penillanura cacereña, entre Cáceres y Malpartida, y un Corcho y una Fuente del Corcho en el baldío de Don Gil, en Torrejón el Rubio. Sin duda, el bosque climácico contaría en la llanura con la encina como especie dominante pero no dejaría de haber ejemplares más o menos numerosos de alcornoques, especie que debió tener asimismo una difusión considerable ${ }^{45}$. En cuanto al roble, es decir, el rebollo o roble melojo, aparece en lugares en los que la pluviosidad alcanza cotas suficientes como Robledillo de Trujillo, entre Garciaz y Berzocana (el Robledo, alturas entre 600-900 metros) o Montánchez (dehesa del Robledo); también aparece la dehesa Rincón de los Robles en tierras alcantarinas. Las zonas situadas por encima de los 600 metros o con humedad edáfica parece que delimitan el entorno ecológico en que este arbol pudo desarrollar su dominio. En cualquier caso, el primer ejemplo citado nos muestra un aspecto que desarrollaremos más tarde: la existencia de topónimos que no se ajustan a la vegetación existente a finales del $\mathrm{XV}$, en lo que supone una clara alteración del clímax. El quejigo, dada su exigencias edáficas, debió tener un menor desarrollo. Sólo se documenta un navaquexigal ${ }^{46}$.

\footnotetext{
130.

${ }^{4}$ Bollórquez, Ibid., 163; AHN, Mesta, caja 39, nº 7; García Oliva, Documentación, doc.

${ }^{45}$ AMT, Leg. 1.1, fols. 12 r. y 14 v; J. GuTIÉRREZ DE LA VEGA (ed.), Libro de la Montería, Madrid, 1976, p. 258; García Oliva, Documentación, doc. 76; AMP, Libro de las Moxoneras, fols. $16 \mathrm{r}$ y $19 \mathrm{r}$. No debemos olvidar que los montes espesos y mohedas se presentan en las normativas de aclarado con un estrato arbóreo diversificado.

"AMP, Libro de las Moxoneras, fol. $30 \mathrm{r}$.
} 
Las referencias a otros arboles como acehuches, madroños o perales nos muestran un bosque complejo con un rico estrato arbustivo. El acehuche no se desarrolla sólo en espacios marginales ${ }^{47}$. El madroño aparece ligado a las zonas de mayor pluviosidad (Madroñera, Navas del Madroño) o humedad edáfica (Charco del Madroño, Majada del Madroño, Fuente del Madroño $)^{48}$. No dejan de mencionarse otros árboles típicos del bosque mediterráneo como el peral silvestre (Arroyo de la Perala), el algarrobo (Garrovillas) y otros menos representativos como las higueras y los granados. El castaño encuentra su desarrollo sólo en las zonas más lluviosas, como las Villuercas o Miravete ${ }^{49}$.

Es llamativo que los pinos tengan una limitada representación y que cuando aparecen (caso de El Pino en Valencia de Alcántara o El Pinarejo, en la Mata de Gibranzos) ${ }^{50}$ el topónimo parece aludir no tanto a un bosque amplio como a espacios limitados. Es este aspecto, junto a la variedad del estrato arbustivo, lo que nos señala un bosque rico y aún con una degradación no muy elevada, que dificulta el desarrollo de series subclimácicas.

Al margen del bosque mediterráneo, la vegetación arbórea de ribera se manifiesta con suficiente amplitud para mostrar una de las características que no están llamadas a permanecer. Las alusiones toponímicas a sauces, fresno y alisos, nos muestras una vegetación de ribera poco degradada en donde se encuentran representados los árboles preferentemente silicícolas. Es llamativo que en este ámbito ecológico sean cuantitativamente más numerosas las alusiones al estrato arbóreo que a las diversas formas de degradación que, sin embargo, no dejan de manifestarse. Aparece una Fuente del Bodonal y corrientes de agua que toman su nombre de los tamujos ${ }^{51}$.

Se documentan ya en estos momentos importantes elementos de degradación que debían tener un peso considerable. Estas formas de degradación alcanzan un grado elevado como se manifiesta en la apreciable

\footnotetext{
${ }^{47}$ Aparece una "majada del aceituna" (Floriano, Ibid., doc. 93, a. 1447).

${ }^{48}$ García Oliva, Documentación, doc. 122, Libro de la Montería, p. 240, AMT, leg. 4, no 3 , fol. $19 \mathrm{v}$.

${ }^{49}$ Libro de la Montería, p. 242; AMP, Libro de las Moxoneras, fols. $30 \mathrm{r}$ y $33 \mathrm{r}$.

${ }^{50}$ Hollórquez, Ibid., 94; AMT, leg. 4, n 3, fol. $15 \mathrm{v}$.

${ }^{51} \mathrm{AMT}$, leg. 10, $\mathrm{n}^{\circ}$ 3, fol. 2 r. y leg. 1, $\mathrm{n}^{\circ}$ 1, fol. 24 r.; Libro de la Montería, p. 240; además, aparece el río Tamuja.
} 
difusión de las diversas clases de jaras ${ }^{52}$. La gran importancia de las cistáceas hay que ponerla en conexión, sin duda, con una importante sobrexplotación ganadera y con la utilización frecuente del fuego para facilitar el desarrollo del pasto y eliminar el matorral no palatable ${ }^{53}$. En estas condiciones de intenso aprovechamiento pecuario, se reduce la competencia que suponen las herbáceas para las jaras, cuyas semillas además toleran muy bien el fuego. Un rasgo llamativo de los jarales es que aparecen en los diversos ámbitos climáticos y orográficos. Se documentan en la penillanura (Mata de Gibranzos, entre La Cumbre y Plasenzuela), y en zonas montañosas como la Sierra de San Pedro (delimitación de las dehesas de Puerto de Carmonita y Mayoralgo), la Sierra de Montánchez (Zarza de Montánchez), la abrupta garganta del Viejas o las estribaciones de Miravete, cerca del Tajo (Jara de Jaraicejo) ${ }^{54}$. Esta proximidad entre este tipo de paisaje vegetal y los osos, un animal forestal por excelencia que tiende a situarse en los lugares donde la actividad antrópica es menos intensa, nos muestra como ya a mediados del siglo XIV la influencia humana llegaba a los diversos entornos ecológicos.

Después de las jaras, las zarzas constituyen el matorral de degradación más importante. Se ubican en lugares llanos con humedad edáfica (hay una Fuente de la Zarza $)^{55}$ o en espacios donde el clímax corresponde al alcornoque y al roble (Zarza de Montánchez).

Las alusiones a otros tipos de vegetación arbustiva son menos abundantes. En general, desarrollan en menor medida formaciones homogéneas o presentan exigencias ecológicas más estrictas ${ }^{56}$. De todos modos, junto a las jaras y zarzas no dejarían de aparecer las típicas especies del matorral de degradación mediterráneo como el lentisco, las aulagas, los romeros o los cardos.

\footnotetext{
${ }^{52}$ En general sólo aparece este nombre genérico que designa a diversas variedades de cistáceas. Tenemos un "xagurçal", en clara referencia al jaguarzo o Cistus Monspeliensis (FLORIANO, Ibíd., doc. 86).

${ }^{53} \mathrm{~J}$. BRAUN-BLANQUET, Fitosociología. Bases para el estudio de las comunidades vegetales, Madrid, 1979, pp. 458 y 466.

${ }^{54}$ FloRIANO, Ibid., doc. 93; Libro de la Montería, pp. 240, 242 y 243.

${ }^{55}$ SÁncilez Rubio, Documentación, III, doc. 57 -cerca de Casillas-.

${ }^{56}$ Aparece una Majada del Helechar en la garganta del Viejas, matorral claramente oromediterráneo en Extremadura (Libro de la Montería, 240).
} 


\subsection{El bosque ideal: un monte hueco de encinas}

El paisaje vegetal dominante es producto de dos fuerzas: la presión sobre los recursos derivado de un crecimiento demográfico y la existencia de un modelo de aprovechamiento del inculto. Este terreno ya no es un espacio salvaje e incontrolado, sino que la actuación antrópica lo modela acorde con sus necesidades.

La actuación humana incide sobre dos elementos que definen el paisaje vegetal: la densidad y forma del arbolado, y la composición específica. El paisaje resultante, o el que se espera obtener, es una dehesa de encinas, entendida ésta en su sentido actual y no en el originario de espacio vedado, defendido.

A finales del siglo $\mathrm{XV}$, son pocos los espacios, con un estrato árboreo abundante y variado, que quedan fuera de la actuación humana. En Valencia de Alcántara quedaban algunos montes espesos o mohedas ${ }^{57}$. Tienen un limitado interés económico salvo en su fase de transición a monte hueco, cuando pueden ser explotados sin grandes limitaciones para la obtención de madera y leña. Escaso es también el aprovechamiento que ofrecen aquellos terrenos donde, debido a la protección, se ha desarrollado un estrato arbóreo denso como sucede en algunas zonas de las dehesas de Zafra y Zafrilla, en Cáceres, o en el Monte del Trigo, en Valencia de Alcántara. En estas condiciones, disminuye drásticamente la producción de bellota pues la lucha inter e intraespecífica consume mucha de la energía de los árboles, que son numerosos y relativamente pequeños. No es extraño que se presenten como improductivos. En el Monte del Trigo, "los montes del dicho Carrascal, por ser muy espessos no davan fruto, y en las dichas tierras ay todavia demasiado monte"; en la Zafra y la Zafrilla, "se an criado muchos montes e carrascales espesos, los quales por ansi estar no creçen ni lievan fruto" ${ }^{58}$. Del mismo modo, el pasto casi desaparece y además es difícilmente aprovechable por el ganado, que encuentra gran dificultad para penetrar en estos lugares ${ }^{59}$. El interés de estos espacios es fundamental y

\footnotetext{
${ }^{57}$ “en los terminos de esta villa ay algunas tierras buenas para labrar, en que ay montes espesos, que se dizen mohedales" (BOIIÓRQUEZ, Ibid., p. 125).

${ }^{58}$ Bollórquez, Ibid. p. 126; García Oliva, Documentación, doc. 122, rub. 76.

${ }^{54}$ Las ordenanzas de Valencia de Alcántara refiriéndose a "sierras e montes bravos y xarales" expresan con gran claridad la dificultad que existe para aprovechar estos espacios de vegetación densa: "los vezinos y moradores desa villa pocas vezes entran a se aprovechar de las pastar ni
} 
casi exclusivamente maderero, pero esto supone para esta sociedad un subaprovechamiento, pues se puede obtener madera y leña en el monte aclarado o dehesa.

En cuanto a las especies vegetales, las ordenanzas de Valencia de Alcántara muestran de modo explícito unas claras preferencias. El bosque de quercíneas es el preferido para subvenir a las necesidades humanas y animales, es decir, para la producción de madera, leña y alimento animal (bellota y ramón). Las ordenanzas citadas nos indican como "los montes de enzinas, robres y alcornoques que ay en el termino desta villa, asy para la gente, que con la madera dellos edifican sus casas, como para los ganados, que de la rama y vellota y lande dellos se sustentan" son "muy nesçesarios y provechosos" (x). Dentro de una explotación integral del arbolado, las demás especies arbóreas presentan una menor diversidad productiva. La vegetación de ribera, por ejemplo, presenta un aprovechamiento más específico -madera en algunos casos- y un escaso interés pecuario; además, es deudora de unas condiciones ecológicas muy específicas ${ }^{61}$. Dentro de las quercíneas, el quejigo aparece en un posición claramente subsidiaria. No se le menciona junto a encinas, robles y alcornoques y aparece poco en las fuentes normativas. Al igual que éstos, ofrece tanto productos madereros como ganaderos ${ }^{62}$, pero el predominio de los terrenos silicícolas en el espacio que estudiamos y sus exigencias pluviométricas limitaron drásticamente su desarrollo.

Dentro de este interés por las quercíneas, la encina aparece con claridad como la especie preferida. El espacio ideal es un monte hueco o dehesa de encinas. La obligación de dejar preferentemente encinas cuando se rozan matas espesas, mohedas o carrascales se repite en las ordenanzas de Valencia de Alcántara hasta un grado que podemos considerar reiterativo.

labrar, ni se pueden dellas aprovechar por su grande espesura de donde se hazen las dichas tierras ynabitables" (BOIIÓRQUEZ, Ibíd., p. 234).

(")BOIIÓRQUEZ, Ibíd., p. 123.

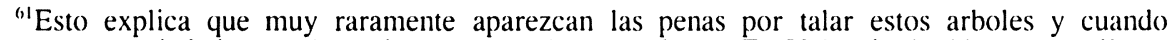
aparecen son inferiores a las existentes para las quercíneas. En Valencia de Alcantara, sólo se pagan trescientos maravedís por cortar un fresno, especie que, con esta salvedad, puede utilizarse libremente "para madera de las casas y para los arados e timones e cosas nesçesarias a la labrança y al coger del pan" (BOHÓRQUEZ, Ibíd., pp. 131). No se menciona el aprovechamiento de su ramón pese a que puede ser consumido por el ganado (J.M. MONTOYA Oliver, Pastoralismo mediterráneo, Madrid, 1983, pp. 46-8).

62J.M. Montoya Oliver, Pastoralismo mediterráneo, pp. 45-6 
También se precisa esta preferencia en una ordenanza trujillana ${ }^{63}$. La razón es que para los hombres del siglo XV la encina es "mas provechosa" ${ }^{64}$. De este modo, hay dos normas de desigual importancia para convertir un bosque denso en uno aclarado: se deben dejar los mayores pies, pero, en primer lugar, las encinas. Un pie de encina aunque sea más pequeño es preferido a otro de alcornoque o roble. Este interés en la encina se debe a las posibilidades que presenta para un aprovechamiento integral. Sólo tiene con el alcornoque la desventaja de que no produce corcho, pero, a pesar de la importancia de la actividad colmenera, este producto tiene en la sociedad tradicional una demanda limitada. Sin embargo, ofrece ventajas importantes. No es la menor de ella su mayor adaptabilidad. Puede darse tanto en climas secos como húmedos, por lo que puede elevarse altitudinalmente hasta competir con el roble melojo o rebollo. Por otro lado, los animales prefieren su bellota, que es dulce y puede ser consumida por el hombre, a la del alcornoque. El alcornoque, con mayores exigencias hídricas, permite el desarrollo de un menor número de árboles y una menor cubierta vegetal, algo de gran importancia para un aprovechamiento integral tanto maderero como ganadero ${ }^{65}$. El rebollo o roble melojo tiene exigencias más específicas y sólo supera a la encina, y de un modo limitado, como productor de madera en el monte bajo, forma de explotación que tiene una escasa importancia en estos momentos ${ }^{66}$. Las ordenanzas de Valencia de Alcántara nos indican claramente como "no son arvores de tanto provecho" ${ }^{\text {" }}$. Parece adivinarse en esta villa una especialización en la explotación de estos dos especies. Así, mientras el carrascal llamado Monte de Trigo "es muy nesçesario para el reparo e sustentaçion de los ganados de los vezinos de la villa", el monte del Carvallar del Maestre (el topónimo nos hace pensar en un predominio del

\footnotetext{
${ }^{63}$ En el carrascal del Monte del Trigo se deben dejar "los arvores mejores y mas prençipales e sean enzinas do las oviere antes que otro arvol $y$, do no oviere monte, mas de çinco o seys arvores aquellos dexen e no los corte y açernaden, ni quemen" (BOHÓRQUEZ, Ibíd., pp. 126; idéntica norma se aplica a las mohedas y tierras labrantías con arbolado denso, pp. 125 y 127); en Trujillo se dispone que "si alguna mata oviere muy espesa que puedan cortar los dichos pies... aunque sean mas gruesos del gordor de la muñeca e que sy la mata fuere muy grande, que syenpre sea obligados a dexar el principal pie della... e si cortaren aquel que fuere quedado para enzina aunque sea mas delgado que la muñeca que caya en la dicha pena" (SÁNCHEZ RUBIO, Documentación, III, pp. 109-10).

${ }^{\circ}$ BOIIÓRQUEZ, Ibid., p. 125.

${ }^{65}$ J.M. MONTOYA OLIVER, Los alcornocales, Madrid, 1980, p. 46.

"WJ. XIMÉnEZ de EMBUn, El monte bajo, Madrid, 1977, p. 61.

${ }^{67}$ BOHÓRQUEZ, Ibid., p. 133.
} 
rebollo) "es muy nesçessario que del se corta y saca la madera para las casas que en la dicha villa e su tierra se hazen" ${ }^{68}$. De este modo, la encina se explotaría de modo integral y, sobre todo, pensando en el aprovechamiento de bellota, ramón y pastos, mientras que del roble se obtendría fundamentalmente madera. No debemos olvidar que esta segunda modalidad de explotación es más difícil de compaginar con la conservación del estrato arbóreo. En Trujillo, la madera de encina, alcornoque y roble se utiliza indistintamente para la construcción ${ }^{69}$.

En definitiva, el espacio arbolado ideal para los hombres del siglo $\mathrm{XV}$ en nuestra zona de estudio es un bosque aclarado de quercíneas en general y específicamente de encinas, susceptible de aprovechamiento ganadero, maderero y agrario. En los lugares de mayor exposición al fuego, el alcornoque, por su mayor resistencia, aparece como un arbol aconsejable $^{70}$. Los bosques monoespecíficos de encina, por tanto, no pueden explicarse sin contar entre otros factores con la actividad humana. Se va a desarrollar una tala selectiva que, al mantenerse las preferencias, producirá consecuencias visibles incluso en la actualidad.

El estrato arbóreo no solo produce bellota, ramón y madera. Al bombear el agua desde niveles bajos permite un mayor y más duradero desarrollo del pasto; asimismo, su sombra reduce la evaporación. También contribuyen al desarrollo del pasto algunas especies del estrato arbustivo dando sombra y, sobre todo, fijando el nitrógeno al suelo. De ahí el interés en mantener, con vistas a la proliferación del pasto, árboles y, en menor medida, arbustos ${ }^{71}$.

La actuación humana produce, como hemos señalado, una dehesa preferentemente de encinas ${ }^{72}$. Las diversas normativas que tienen como

\footnotetext{
${ }^{68}$ BOHÓRQUEZ, Ibid.., p. 126.

${ }^{69} \mathrm{AMT}$, leg. 6, no 8, fol. 185 r.; leg. 3, n 2.1, fols. 129 r., 143 r., 149 r., 182 v., 214 r., 220 r. y 241 .

${ }^{70}$ BOHÓRQUEZ, Ibíd., pp. 123-5.

${ }^{71}$ Una ordenanza de Trujillo de 1516 pena la obtención de leña y escoba de las dehesas de la carnicería y boyal porque "la escoba e monte dellas es provechoso para criar el pasto della para los bueyes e para las vacas de la carneçeria" (SÁNCIIEZ RUBIO, Documentación, III, p. 62). Retamas y escobas fijan el nitrógeno al suelo (M. PEInADo y J. Ma MarTíneZ, El paisaje vegetal de Castilla-La Mancha, Albacete, 1985, p. 34).

${ }^{72}$ En determinadas circunstancias puede elégirse otra especie: V. CLEMENT, Frontière, reconquête et mutation des paysages végetaux entre Duero et Système Central du XI au milieu du XV" siècle, "Melanges de la Casa de Velázquez", XXIX/1 (1993), p. 108; A. CORTONESI, La silva contesa. Uomini e boschi nel Lazio del Duecento, "Il bosco nel Medioevo", Bolonia,
} 
finalidad proteger el monte y optimizar su explotación integral intentan modelar un paisaje con unas características precisas, que no siempre se plasmará en la realidad debido a la presión humana. De este modo, se fija un paisaje ideal que incide en la densidad y forma del arbolado.

Las normativas sobre las distancias que deben guardarse entre árboles no son de fácil interpretación. La de Valencia de Alcántara, treinta pasos para montes bravos o mohedas que se roturen para labranzas, podría originar una dehesa muy similar a la actual con unas decenas de arboles por hectárea. Sin embargo, en Cáceres la distancia entre árboles sería de doce varas (10,03 ms.) en la Sierra de San Pedro y los Orellares y de diez en la Zafra y Zafrilla (8,36 ms.); en Alcántara, de una soga (8 varas); y en Trujillo, de ocho pies $(2,24 \mathrm{~ms}$.) para encinas, alcornoques y quejigos y de dieciseis $\left(4,48 \mathrm{~ms}\right.$.) para robles ${ }^{73}$. Excepto en Valencia de Alcántara, las distancias serían cortas y no superarían, salvo de modo ligero y excepcional, los diez metros. Estamos, por tanto, ante un bosque denso que permitiría alcanzar el centenar de arboles por hectárea, cuando en la actualidad se tiende a menos de la mitad. Esto supondría un recubrimiento teórico claramente superior a la mitad del suelo ${ }^{74}$. De todos modos, las normativas aluden no tanto a una dehesa consolidada cuanto preferentemente a su creación a partir del monte bajo (normativas trujillanas y cacereñas; sólo parcialmente en las de Valencia de Alcántara) en donde los arboles son pequeños y pueden permitirse altas densidades antes de la obtención de un monte hueco maduro. Es posible, de todos modos, que la forma de

1988, p. 309; G. Cherubini, La 'civilta' del castagno alla fine del Medioevo, "L'Italia rurale

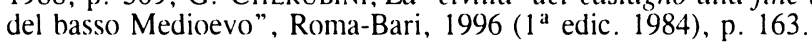

${ }^{73}$ Bollórquez, Ibíd, pp. 124, 125 y 127; AHN, Mesta, caja 8, no 12; García Oliva, Documentación, doc. 122, rubs. 75 y 82; SÁNCHEZ Rubio, Documentación, III, p. 46. Para las medidas citadas: M. BASAS, Antiguos sistemas de pesos y medidas, Bilbao, 1980, p. 46; F. Lopera, Equivalencias agrarias, métricas, de longitud y de peso, Madrid, 1958, p. 40; J. VAllvé, Notas de metrología hispano-arabe. II. Médidas de capacidad, "Al-Andalus", XLVII/1 (1977), pp. 71-2; Pesas, medidas y monedas, Granada, 1986; L. BESNIER ROMERO, Medidas y pesos agrarios, Madrid, 1964, p. 14.

${ }^{74}$ J.D. PARSONS, La economía de las montaneras en los encinares del suroeste de España, "Estudios Geográficos", XXVII/103 (1966), p. 319, señala que normalmente los arboles se suelen dejar a unos quince metros, con lo que la copa sólo da sombra a la mitad del suelo como mucho, y normalmente a menos. Sobre el recubrimiento, debemos considerar que una encina que tenga a 1,30 metros del suelo un grosor de entre $105-119 \mathrm{cms}$. cubre $54 \mathrm{~m}^{2}$ y si es de 120 134, $66 \mathrm{~m}^{2}$ (J.M. MONTOYA Oliver, Encinas y encinares, Madrid, 1989, p. 98). 
explotación de los espacios adehesados permitiera densidades superiores a las actuales ${ }^{75}$.

La obtención de madera y leña era constante en este espacio vegetal; además, el ramón suponía un complemento en la alimentación del ganado. El arbol adquiría, de este modo, una forma peculiar. En primer lugar, dado que la dehesa es una modalidad de monte alto, los pequeños arboles de quercíneas se cortaban "por lo baso e por los sobacos de los arvoles entresacando que puedan colar e pasar los bueyes que araren syn fazer perjuyzio en los arvoles nuevos"76. La ramificación del arbol comienza así a cierta altura del suelo. Esta actuación se realizaría tanto en carrascales o montes bajos que se querían preparar para una explotación integral ganaderomaderera como en las mohedas. No era la única actuación humana tendente a modelar el arbol. La obtención de leña y ramón dotaría al estrato arboreo de unas características pecualiares. En general, las podas realizadas a los árboles podemos considerarlas severas, pues normalmente sólo se les dejaría dos ramas $^{77}$. En Valencia de Alcántara, tras el desmoche quedaría "un ramo, el más prinçipal, que sube derecho hazia arriba en lo mas alto del arvor y otro mas baxo, al medio del arvor, e qualquiera parte del con tanto que sea el mas prençipal de los que se dizen aljamas" ${ }^{78}$. El arbol se desarrollaría en altura y tendría una forma más elevada que achaparrada. En Alcántara, no se pueden cortar "ensinas ni alcornoques syn dexar horca e aljuma que hera el rramo mas alto de cada uno de los dichos arboles"79. En Cáceres, la normativa no es muy diferente. Hay que dejar, igualmente, horco y aljuma, es decir, el ramo principal que se eleva en sentido vertical y una de las ramas principales. En el acuerdo de vecindad con Trujillo de 1497 se precisa más: “a lo menos la una rama entera e el horco de dos palmos ençima de la horcadura del arbol" ${ }^{80}$. En Trujillo, dejando al lado

\footnotetext{
${ }^{75}$ A. RUPÉrez CuÉllar, La encina y sus tratamientos, Madrid, 1957, pp. 66-8. Las ordenanzas de Salamanca de 1567 estipulan 30 arboles por fanega (D.E. VASSBERG, Tierra y sociedad en Castilla. Señores, "poderosos" y campesinos en la España del XVI, Barcelona, 1986, p. 63).

${ }^{7}$ 'SÁnchez Rubio, Documentación, III, p. 46.

${ }^{77}$ En la actualidad se considera más aconsejable dejar tres: J.L. Ramos Figueras, Selvicultura, Madrid, 1979, p. 479; A. RUPÉREZ CUÉLlaR, Ibíd., p. 80

${ }^{78}$ Bollórquez, Ibid., p. 126 (para ramón de bueyes); en el mismo sentido, p. 133 (para la obtención de leña).

${ }^{79} \mathrm{AHN}$, Mesta, caja 8, no 12.

${ }^{811}$ García Oliva, Documentación, docs. 51, 122, rúbs. 9 y 10, y 175, rúb. 3.
} 
el acuerdo de vecindad citado, las podas se realizan respetando parcialmente todas las ramas que sólo se cortarán a la altura de una vara (en el monte viejo se desmochara "por lo alto dexando los pulgares de una vara de medir e dexando todos los pulgares que el tal arvol tuviere") ${ }^{81}$. El arbol está en mejor disposición de recuperarse y de recuperar su forma natural, menos elevada que achaparrada. Es posible que estas normativas escondan dos fases en la explotación y conservación del bosque, pero, de ser así, resultaría sorprendente que se desarrolle un mayor conservacionismo en Trujillo, dotado de buenos bosques.

Estas normativas están referidas a encinas y alcornoques. Para otras especies, las normativas son más permisivas. El único interés es que no se corten por el pie, para que sigan produciendo madera. En Valencia de Alcántara, se pueden cortar todas las ramas a los robles para obtener leña y a los fresnos para obtener madera ${ }^{82}$. Las podas severas que se realizan a encinas y alcornoques quizás explique que se utilicen intervalos importantes, diez años, superiores a los que normalmente se practican en la actualidad ${ }^{83}$.

\subsection{Panorámica general}

La información que nos suministra Fernando Colón y el resto de las fuentes nos permite hacernos una idea bastante aproximada del estado de la vegetación natural a finales del siglo XV y primeras décadas del XVI. La zona que estudiamos se caracteriza por un claro predominio de los espacios ganaderos y una débil dedicación agraria. Ésta se integra, en gran medida, dentro de las dehesas que se convierten de este modo en explotaciones agropecuarias. Sin embargo, los paisajes específicamente agrarios monopolizados por tierras de pan llevar, huertos y viñas serían escasos. Fernando

\footnotetext{
${ }^{81}$ SÁNCIIEZ RUBIO, Documentación, III, p. 46; sin embargo en un pleito entre Trujillo y la Mesta, ésta señala su derecho a cortar ramas de encinas dejando horco y aljuma, lo que nos indicaría unas normas similares a las de otros concejos (AHN, Mesta, caja 212, $\mathrm{n}^{\mathrm{o}} 19$ ).

${ }^{82}$ BollóRQUEZ, Ibíd., pp. 131 y 133; este sistema, que sólo deja la guía terminal, según J.L. RAMOS FIGUERAS, Selvicultura, pp. 479-80, "afecta la vitalidad de los pies y por otra parte disminuye el coeficiente morfico de los fustes, haciéndoles muy cónicos y por tanto con aprovechamiento maderable deficiente".

${ }^{83}$ BoHórquez, Ibíd., p. 133; SÁNCHEZ Rubio, Documentación, III, p. 46.
} 
Colón sólo los menciona entre Cáceres y el Casar ${ }^{84}$. Esa virtual ausencia de las tierras de labranza dentro de la descripción de Fernando Colón se explica en parte por la utilización de la legua como unidad de medida. A esta escala, sólo serían perceptibles las tierras adehesadas.Tampoco aparecen otras formas de vegetación que hacia el 1500 podemos considerar residuales como los montes con un arbolado denso. Ya hemos indicado su probable existencia en Valencia de Alcántara, donde incluso podían darse en zonas aptas para el cultivo ${ }^{85}$. Estos espacios se ubicarían en las límites de los terminos municipales y en las zonas montañosas. En general no creemos que fueran de una extensión considerable, sino más bien pequeños rodales. En cuanto a las mohedas, las dos únicas documentadas, no parecen alterar el desarrollo normal del amojonamiento de las dehesas de Mayoralgo y Mayoralguillo y la del Puerto de Carmonita ${ }^{86}$.

Hemos señalado que tomando como medida la legua el espacio adehesado es omnipresente en la cuenca meridional del Tajo. La información de Fernando Colón es clara. Sin embargo, estos espacios presentan grados de conservación muy diferentes. En muchos casos se alude a encinares o montes de encinares. Estamos ante la típica dehesa con un estrato arbóreo suficientemente desarrollado como para marcar la característica central del paisaje. Otras veces se habla de dehesa a secas. El espacio concreto al que se aplica esta denominación, el término de Trujillo, nos permite afirmar que no estamos ante un espacio diferente con una menor cubierta arbórea, sino ante dos terminos con significado muy similar. Si hay, sin embargo, un contraste entre éstos encinares o dehesas y la dehesa de hierbas o herbaje. El espacio entre Alcántara y Carbajo se define como "seis leguas de tierra

\footnotetext{
${ }^{84}$ “Dos leguas de tierra doblada la primera de tierra de labrança e la postrera de montes de enzinares e de berrocales" (F. COLÓN, Descripción y cosmografía de España, 3 vols., Madrid, 1908-1917, II, p. 131); sin embargo, más adelante habla de "dos leguas llanas e de paramo de yerva" (Ibid., II, p. 293).

85 "en los terminos de esta villa ay algunas tierras buenas para labrar, en que ay montes espesos, que se dizen mohedales" (BOHÓRQUEZ, Ibíd., p. 125).

80" Alderredor de los terminos de la villa e dentro dellos ay muchas sierras e montes bravos e xarales que parten e confynan con los lugares y villas y dehesas" (BOHÓRQUEZ, Ibíd., p. 234); sobre las mohedas señaladas, FloRiano, Ibid., doc. 103; en las Ordenanzas del Monte de Cáceres, las sierras de la Mosca y Aguas Vivas, entre las cuales se ubica esta ciudad, se encuadran entre los espacios más arbolados del término (GARCía Oliva, Documentación, doc. 122, rúb. 79 ).
} 
doblada mucho e de dehesas de yerbas, e las leguas postreras son de tierra grafosa e de enzinares" ${ }^{87}$.

La información que nos ofrece Fernando Colón (mapa 1) presenta una concordancia con la obtenida en otras fuentes, lo que nos permite valorar el estado de la cubierta vegetal en nuestra zona y nos ayuda a comprender ciertos problemas que tienen un reflejo claro en la documentación. Dentro del predominio que el paisaje adehesado tiene en la vertiente meridional del Tajo, podemos señalar al menos cuatro zonas claramente diferenciadas que presentan un perfil pecualiar. Estas zonas se constituyen en torno a Alcántara-Brozas, Cáceres, Trujillo y la antigua tierra de Plasencia.

La primera abarca gran parte de la jurisdicción alcantarina, excluida Valencia de Alcántara. Estamos ante un territorio donde el bosque adehesado ha sufrido un ataque considerable. Ya desde las primeras décadas del siglo XV se documenta la escasez de bosques en Alcántara y Brozas. En 1422, los vecinos de Brozas solicitan al maestre permiso para cortar madera en el monte de la dehesa de Araya y en los demás de la orden. En 1436, los de Alcántara solicitan cortar madera "en todos los montes"; a finales del siglo se benefician de un trato preferente para sacar madera de Valencia de Alcántara $^{88}$. Según Fernando Colón, entre Alcántara y los lugares de Mata y Aldea del Rey hay dehesas de encinas; sin embargo, solo hay herbajes hacia Carbajo y Membrío, mientras que hacia Salorino hay un terreno desarbolado. En Brozas también hay una situación de equilibrio entre los caminos con dehesas de encinas y los espacios poco o nada arbolados. Esta concentración de espacios desarbolados es claramente superior a la que presentan las demás zonas. Un conflicto entre Alcántara y la Mesta en 1523 nos confirma como el termino de Alcántara presenta un arbolado sobre el que se impone un rígido control para evitar su desaparición. Más que los argumentos de la villa es la propia institución ganadera la que confirma esta situación al señalarnos la existencia de un arbolado no solo escaso sino de escaso porte, consecuencia de una tala abusiva ${ }^{89}$. La delimitación de la

\footnotetext{
${ }^{87}$ F. COLÓN, Ibid., I, p. 84.

${ }^{88}$ A. DE TORRES Y TAPIA, Ibíd., II, pp. 249 y 307; BOHÓRqUEZ, Ibíd., p. 132; Plasencia también sería una zona de abastecimiento de madera a principios del XVI (AMP, Actas municipales de $1522-6$, fols. 285 r. y 337 v.).

${ }^{89 . " e n ~ m u c h a s ~ p a r t e ~ d e ~ l o s ~ d i c h o s ~ t e r m i n o s ~ n o ~ a v i a ~ m o n t e ~ q u e ~ s e ~ a v a s t a s e ~ p a r a ~ h a s e r ~ p u e n t e s ~}$ sy no dexasen horca e aljuma" (AHN. Mesta, caja 8, $\mathrm{n}^{\circ} 12$ ).
} 
cañada que atraviesa el término de Brozas de norte a sur, realizada en 1501, nos presenta también un espacio con escasa vegetación en donde sólo se mencionan carrascales ${ }^{\text {*) }}$.

Dentro del territorio alcantarino, el término de Valencia de Alcántara y el espacio que rodea Salorino, con orografía más abrupta, presentan una cubierta vegetal más abundante. En Valencia de Alcántara aún aparecen mohedas sobre terrenos aptos para la agricultura y se alude en repetidas ocasiones a montes bravos, terrenos que se presentan como especialmente indicados para la roturación. Más importante es que sea una zona que suministra madera a otras aldeas y villas alcantarinas e incluso de fuera de la jurisdicción. Salorino aparece rodeado de encinares ${ }^{91}$. Con una densidad a principios del siglo XVI de 0,19 vecinos $/ \mathrm{km}^{2}$, la presión sobre el estrato arbóreo sería escaso.

Otro conjunto que presenta unas características definidas es el alfoz cacereño. Con una densidad de población inferior a la de Brozas o Alcántara, e igualmente a la de Valencia de Alcántara o Trujillo, y sin presentar una situación tan dramática como la de los dos primeros lugares citados, el espacio adehesado ha sufrido una transformación importante. A principios del XVI, esta transformación se constata sobre todo alrededor de la villa, donde mayor concentración alcanzan los espacios desmontados y degradados (jarales). Sin duda, esto aparece como consecuencia clara de la influencia de la villa y su mayor población. Los terrenos que rodean a las aldeas mantienen mejor el paisaje habitual de los espacios adehesados: sólo los trayectos Casar de Cáceres-Garrovillas, Torreorgaz-Alcuescar y Malpartida-Aliseda presentan un paisaje degradado. Arroyo, Malpartida y el Casar, las aldeas que presentan más información, están rodeadas de dehesas de encinas. El concejo de Cáceres aún tiene terrenos montuosos con un arbolado abundante (Sierra de San Pedro, Sierras de la Mosca y Aguas Vivas, etc.). La degradación del paisaje vegetal en el alfoz cacereño se debe más que a una débil densidad de población $\left(0,9\right.$ vecinos-pecheros $/ \mathrm{km}^{2}$ en 1532) a la intensidad de los adehesamientos, que llegan a cubrir en el siglo

\footnotetext{
${ }^{90} \mathrm{AHN}$, Mesta, caja 39, no 7.

91"lugar de treinta vecinos esta en un cerrillo entre unos enzinares" (F. COLÓN, Ibíd., I, 182).
} 

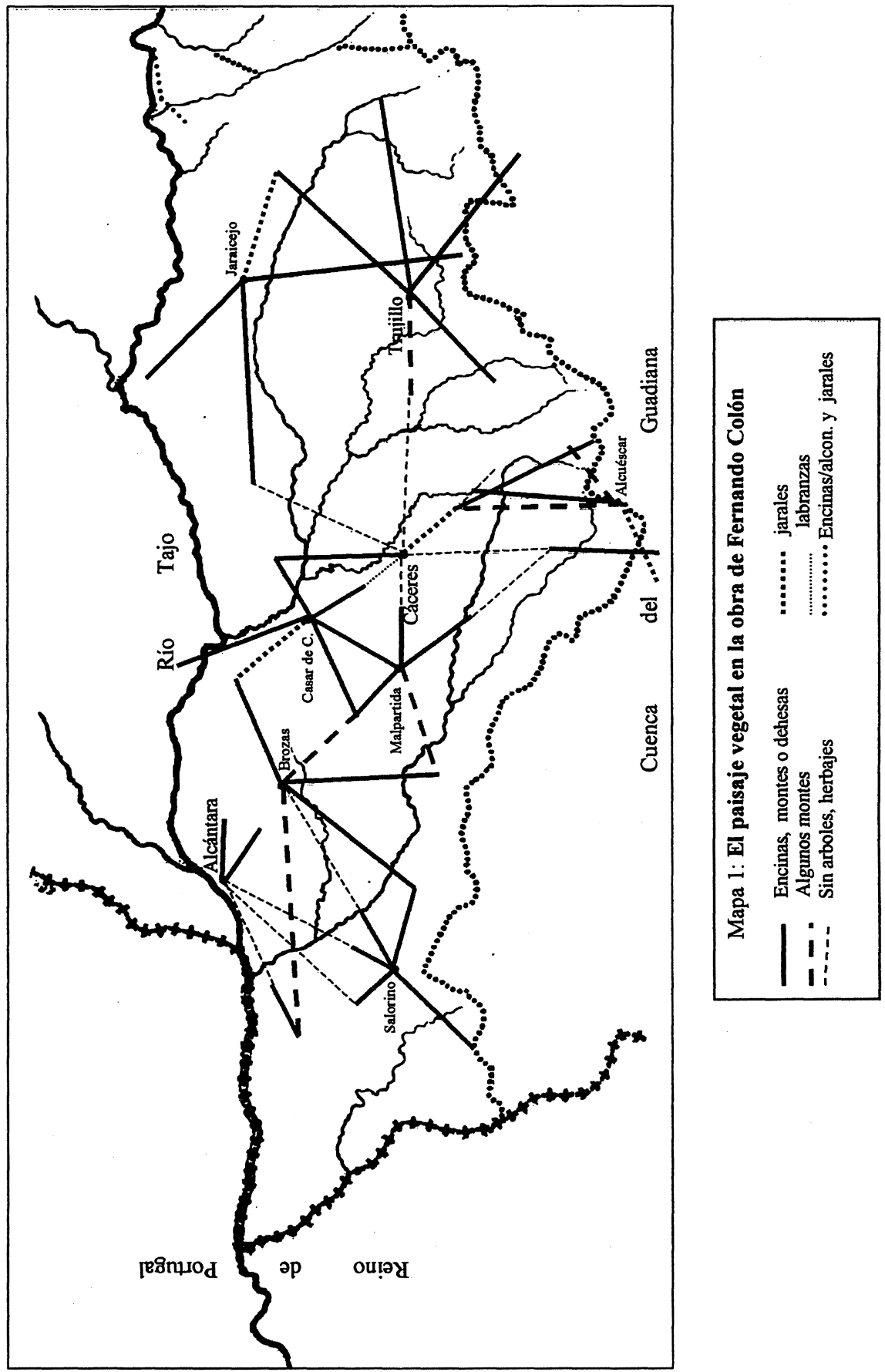
XVI el $89 \%$ del término ${ }^{92}$. Cáceres también es deficitario en madera ${ }^{93}$.

El termino de Trujillo presenta unas características definidas. Pese a contar con una mayor población que Cáceres $\left(1,51\right.$ vecinos-pecheros $/ \mathrm{km}^{2}$ en 1531-2), es un territorio excedentario en leña y madera. En la obra de Fernando Colón, Trujillo aparece rodeado de dehesas, sin más especificación, aunque para los demas lugares se habla de encinares o de herbajes o dehesa de herbajes. No se menciona ningún fenómeno de degradación, aunque conocemos la pobre vegetación arbórea que aparece en el berrocal trujillano, que rodea la villa, o en la Mata de Gibranzos, ubicada en la penillanura entre La Cumbre y Plasenzuela. Son lugares, sin embargo, susceptibles de un aprovechamiento silvícola. La ambigüedad que pudiera tener la información que nos suministra Fernando Colón desaparece con otros datos suministrados por las fuentes. El termino de Trujillo contaba con una rica cubierta forestal. El interés del monasterio de Guadalupe por abastacerse en él es ilustrativo, si bien, las afirmaciones del prior quizás sean exageradas $^{94}$. Ya hemos indicado como un vecino de Cáceres y otro de Jaraicejo aparecen aprovisionándose de leña en Trujillo ${ }^{95}$.

El reparto de mil quinientas cargas de leña realizado en 1482 nos permite captar la desigual densidad que la cubierta vegetal tiene en las diversas comarcas del alfoz. La penillanura presenta densidades claramente inferiores a las de la comarca serrana de Garciaz y Berzocana. Mientras en la primera zona las cantidades oscilan enre 0,39 y $0,81 \mathrm{cargas} / \mathrm{km}^{2}$, en Garciaz llega a 1.09 y en Berzocana a $1,12^{96}$. Otros indicios refuerzan lo señalado. Por un lado, los deslindes de la zona de Garciaz y Berzocana presentan mucha más vegetación que los del Berrocal o la Mata de Gibranzos. Por otro, en el Libro de Daños en los montes es llamativo no tanto la mayor cantidad de arboles mencionados en los dos primeras aldeas

\footnotetext{
${ }^{92}$ E. Cabrera y G. Lora, Ibíd., p. 65; J.L. Pereira, Estructura agraria de Cáceres y su tierra en el siglo XVI (tesis doctoral), Cáceres, 1982, 334-336.

${ }^{93}$ En 1498, Juan de Cáceres solicita sacar de Trujillo treinta cargas de leña para un molino en Cáceres (AMT, leg. 6, $\mathrm{n}^{\circ}$ 8, fol. 168 r.); en 1523, Francisco de Paredes, vecino igualmente de esta villa, hace lo mismo en Plasencia (AMP, Actas municipales de 1522-6, fol. 71 v.).

${ }^{9+4}$ en esa dicha çibdad e su tierra ay pastos y enzinares tantos e de tanta abundançia en que muy muchos e demas cantidad que los ganados que ay en esa çibdad se pueden mantener" (SÁncilez RubIo, Documentación, I, doc. 78, a. 1481); en 1440 el monasterio ya había obtenido un privilegio para abastecerse en Trujillo de productos silvícolas (Ibíd., I, 61).

${ }^{95} \mathrm{AMT}$, leg. 3, n⿳2 2, fol. 277 r., año 1515.

${ }^{\%} \mathrm{AMT}$, leg. 4, $\mathrm{n}^{0} 7$, fol. $108 \mathrm{v}$
} 
citadas, que podía deberse a una mayor agresión al bosque, como el hecho de que nos informe de transgresiones que afectan simultáneamente a trescientos dieciocho robles desmochados en Garciaz o a doscientas encinas chamuscadas en Berzocana; en La Cumbre, la mayor transgresión afecta sólo a cuatro encinas ${ }^{97}$

La tierra de Montánchez quizás pueda asimilarse a Trujillo en su cubierta vegetal, aunque presente una mayor degradación. Junto a espacios con poco o ningún arbolado otros espacios parecen tener suficiente vegetación natural. Hay diversos indicios que, más que la escasas información de Fernando Colón, nos permiten esbozar alguna idea. No tenemos noticias de la escasez de bosque en su territorio, que alberga a finales de la Edad Media poblaciones de osos, animal típicamente forestal. Contaría con encinas y alcornoques junto a robles y quejigos, lo que aboga por una variada cubierta vegetal. Por otro lado, su carácter parcialmente montuoso favorecería la permanencia del arbolado.

Una cuarta zona es el territorio de la antigua tierra de Plasencia que se extendía entre el Almonte y el Tajo, espacio preferente de la señorialización laica y eclesiástica. En 1528 no está muy poblado y ningún lugar supera los 3 vecinos pecheros $/ \mathrm{km}^{2}$ : Jaraicejo llega a 2,96, pero Deleitosa sólo alcanza 1,44 y Monroy, 0,81. Fernando Colón no presta gran atención a esta zona. En el espacio comprendido entre el camino Jaraicejo-Monroy y el Tajo, dehesas de encinas ocupan gran parte del territorio. El paisaje adehesado domina también el espacio al norte del Almonte que linda con el sector nororiental del alfoz trujillano. Entre Jaraicejo y Deleitosa se ha desarrollado un paisaje de jaras. En la zona oriental, entre Talavera la Vieja y Avellaneda (aldea de Talavera de la Reina), éstas forman asociación con encinas y alcornoques. Junto a espacios degradados aparecen dehesas en un buen estado de conservación. Sin embargo, a mediados del siglo XVI, Deleitosa, junto con Almaraz y Belvís, intenta aprovisionarse de madera en los pinares placentinos, intentado que la señorialización no rompa antiguos derechos $^{98}$.

\footnotetext{
${ }^{97} \mathrm{AMT}$, leg. 10, n" 5, fols. 10 r. y 83 v.

${ }^{98} \mathrm{AMP}$, Carta ejecutoria de 1555; Juan II confirmó estos derechos, posteriormente discutidos, en 1451 ( 37 v. -38 r.)
} 


\subsection{Las especies vegetales: el predominio de las quercíneas}

La encina aparece en la obra de Fernando Colón como un arbol omnipresente. Sólo en la zona que linda con el concejo de Talavera, encinas y alcornoques se equiparán. Este dominio de la encina no puede extrañarnos tanto por razones ecológicas como por la actividad humana. Sin embargo, una aproximación más detallada permite captar una realidad más compleja. Junto a la encina, no dejan de aparecer otras quercíneas, mientras que las demás especies arbóreas, que no debían estar subrepresentadas en los amojonamientos, mantienen una presencia residual.

La penillanura y las zonas montañosas, que superan los 450-500 metros, presentan características claramente diferentes. En la penillanura, la encina tiene un predominio acusado, correspondiendo al alcornoque una función de acompañamiento. Hay ejemplos en los que parece darse un estrato arbóreo monoespecífico. Así sucede en las dehesas y baldíos situados entre Monroy y Torrejón el Rubio. Salvo un mesto, que aparece en el baldío de Brezalejos, todos los demas arboles citados son encinas, que representan más del $99 \%{ }^{99}$. Una realidad similar se documenta en la zona más próxima al Tajo, en la delimitación de los términos de Talavera la Vieja-Alija y Talavera de la Reina, realizada en $1495^{100}$.

La delimitación de Cáceres y Alcántara de 1496 entre el Puerto de Albocar, o Media Cacha, y el arroyo del mismo nombre, afluente del Salor, también muestra como en las estribaciones más suaves de la Sierra de San Pedro, partiendo de alturas máximas que rondarían los 400 metros de altitud, predominan las encinas; junto a ellas hay una pequeña cantidad de alcornoques, que parece situarse en la zona más cercana al puerto. Las primeras representan el 93,7\% de los árboles citados (treinta y seis encinas y dos carrascos), mientras los segundos solo alcanzan el $4,9 \%$. Una realidad muy

\footnotetext{
${ }^{99}$ Aparecen citadas setenta y seis encinas y cinco carrascos, pero en las dehesas de Moheda y Chistes, en el Baldío de Don Gil y en el deslinde entre el baldío de Plasencia y Monroy se alude a encinas en general en varios mojones y en el baldío de Brezalejos y la dehesa de Saucedilla de las Casas en dos casos se hace referencia a un número no precisado de carrascos (AMP, Libro de las Moxoneras y deslinde de la dehesa de la Cortilla; ACP, leg. 138, $\mathrm{n}^{\circ} 2$ y leg. $\left.1, \mathrm{n}^{\circ} 39\right)$.

${ }^{1(x)}$ Se mencionan tres encinas, dos carrascos y un número indeterminado de éstos (AHPC, Ayunt. de Talavera la Vieja, reg. 1, fols. 16 r.-17 r.).
} 
similar se documenta en las suaves elevaciones de la Sierra de Santo Domingo, límite entre los concejos de Arroyo de la Luz y Alcántara ${ }^{101}$.

Este predominio de la encina en la penillanura, aunque con menos precisión, se documenta en todo el resto del territorio. En Trujillo, los deslindes más abundantes no corresponden a este espacio. Sin embargo, es llamativo que en la Mata de Gibranzos, entre La Cumbre y Plasenzuela, aparezca una encina y en el Berrocal de Trujillo dos carrascos en el deslinde de 1353 y tres en el de 1493. Más importantes son los datos suministrados por el Libro de daños en los montes. En la mayor parte de los lugares de la penillanura sólo se mencionan encinas. Así sucede con Trujillo (muy llamativa la numerosa información relativa al Cabo de Tozo), Aldea del Obispo, las Huertas, La Cumbre y Plasenzuela. En el deslinde de la cañada de Brozas aparecen carrascales (que no sabemos hasta que punto corresponden a topónimos o a vegetación realmente existente), lo que denota un claro predominio de la encina. En Alconétar, en el acuerdo de vecindad suscrito con Cáceres sólo se protege esta especie. Cerca de la desembocadura de la garganta de Riofrío en el Tajo, en 1537, la encina asienta un dominio que no se mantiene a mayor altura ${ }^{102}$.

El alcornoque no desaparece en la penillanura. Es sintomático que aparezca citado junto a las encinas en las ordenanzas de Alcántara. Igualmente, en el Libro de daños en los montes de Trujillo se mencionan veintidós en Aldea del Pastor y están bien representados en Ruanes. En sendos amojonamientos, se documentan entre Casas de Don Antonio y el arroyo de Zorita, y cerca de la Sierra de Santo Domingo, entre Arroyo de la Luz y Navas del Madroño ${ }^{103}$.

El acehuche, asociado al lentisco, al igual que en zonas montañosas, aparece en la penillanura en lugares próximos al Tajo, en la Hoz de Malueñes; cerca del camino que une Zarza de Montánchez y Robledillo de Trujillo; e incluso en mitad del río Salor, junto a un fresno, favorecido por la desaparición de otras especies ripuarias. Un "azauchal" se documenta

\footnotetext{
${ }^{101}$ García Oliva, Documentación, doc. 167; AMAL, leg. 625, nº 1, fols. 37 r., 40 r., 54 r. y $58 \mathrm{r}$.

102AMT, legs. 4.3, fol. 18 v.; 1.1 , fols. 99 v., 112 r. y 114 r.-v.; y 3.1 , fols. 411 v., 412 r. y 421 r.; AHN. Mesta, Caja 39, no 7; García Oliva, Documentación, doc. 51; AMP, Libro de las Moxoneras, fol. $22 \mathrm{v}$

${ }^{1103} \mathrm{AMT}$, leg. 10, n⿳0 5, fol. 80 r. (Aldea del Pastor) y 40 v. y 54 v. (Ruanes); Floriano, Ibid., doc. 72: Garcia Oliva, Documentación, doc. 66.
} 
cerca de la sierra de Santo Domingo en 1516. En Alcántara está entre las especies citadas junto a las quercíneas ${ }^{104}$. Su presencia es residual. El galapero aparece asociado a la encina entre el puerto de Media Cacha y el arroyo de Albocar ${ }^{105}$, respondiendo seguramente al aumento de la pluviosidad. Esta razón explica también la aparición de madroñeras en un espacio dominado por la encina en la Sierra de Santo Domingo y espacios colindantes $^{106}$.

El predominio de la encina, en todo caso, en la penillanura es claro. Sin duda, este predominio tiene un componente climático, pero la labor humana no ha debido ser despreciable. En cualquier caso, esta actuación en la penillanura no siempre se presenta con claridad. Sin embargo, algunos ejemplos son ilustrativos. El predominio tan acusado de la encina en el territorio de la antigua tierra de Plasencia choca con ciertas evidencias toponímicas. El baldío de Brezalejos, donde aparece un mesto, o los topónimos Fuente del Corcho, en el baldío de Don Gil, o El Corcho, entre este baldío y Jaraicejo ${ }^{107}$, nos muestran la preexistencia al lado de la encina del alcornoque y sus formas de degradación.

En los moderados relieves montañosas que aparecen en la zona que estudiamos, el paisaje vegetal presenta otro perfil. El alcornoque, el roble melojo o rebollo, casi siempre citado como roble a secas, y el quejigo ganan peso de modo creciente. Es en este contexto en el que la encina no tiene ventaja frente a sus competidores donde los indicios de la actividad humana son más evidentes. En función de la altura y la pluviosidad, el paisaje vegetal presenta dos tipos de asociaciones arbóreas. En la primera aparecen las mismas especies que en la penillanura, aunque con un peso diferente; en la segunda, se presentan encinas, alcornoques, robles y quejigos.

El roble, por sus exigencias climáticas y menor valoración, encuentra un menor desarrollo que la encina o el alcornoque. En cualquier caso, no se presenta en alturas inferiores a los seiscientos metros. Por ello no aparece

\footnotetext{
${ }^{114}$ AMP, Libro de las Moxoneras, fol. 22 r. ("azauches e un arbol que dizen charneca"); AMT, Leg. $6, n^{\circ} 1$, fol. 10 v.; García Oliva, Documentación, doc. 122, rub. 92; AMAL leg. $625, \mathrm{n}^{\circ} 1$, fol. $76 \mathrm{r}$. (el lentisco es abundante en esta zona, aunque aparece asociado al matorral: fols. 37 v., 39 v. y 64 r.); AHN, Mesta, caja 8, n 12 .

${ }^{105}$ Garcia Oliva, Documentación, doc. 167.

${ }^{11 k} \mathrm{AMAL}$, leg. $625, \mathrm{n}^{0} 1$, fols. 38 r., 40 v., 62 v., 64 r. ("el monte hera tan espeso e rezio con xaras e madroño e breço e lentisco que no podian llegar alla") y $74 \mathrm{v}$.

${ }^{1177}$ AMP. Libro de las Moxoneras, fols. 14 v., 18 r., 19 r. y 98 r.
} 
nunca citado entre las especies vegetales de la tierra de Cáceres. El quejigo, que une a sus exigencias climáticas otras edáficas menos adaptadas a nuestro entorno, encuentra un menor desarrollo.

Algunos deslindes nos permiten captar en espacios concretos la influencia que la altura ejerce sobre el paisaje vegetal. Entre el nacimiento de la garganta de Riofrío en la Sierra de Miravete y el Tajo pasamos de los setecientos a los trescientos cincuenta metros. En las proximidades del Tajo se documenta la encina, pero muy pronto el alcornoque impone su dominio; en las proximidades del nacimiento de la garganta aparece la asociación alcornoque-quejigo, si bien de este último sólo hay matas ${ }^{108}$. Aunque de modo mucho menos claro y matizado en la garganta de Helechoso, en la confluencia de los términos de Deleitosa, Jaraicejo y Casas de Miravete, parece existir una relación entre altura y especies vegetales, excluyendo a la encina, similar ${ }^{109}$. En el deslinde de los términos de Trujillo y Montánchez, que en el valle del Tajo descienden desde el Puerto del Asno (actua Puerto del Burro) hasta la penillanura por el Arroyo del Mojón, es muy ilustrativo, pese a la dificultad de precisar la ubicación concreta de los distintos mojones, que el orden de los arboles citados sea roble, quejigo y alcornoque $^{110}$. Las especies más exigentes en agua ocupan las zonas más elevadas y en las más bajas se impone el alcornoque. El roble, aunque menos que el quejigo, debía ser en cualquier caso una especie marginal en estas estribaciones montañosas ${ }^{111}$.

La sierra de San Pedro, con relieves moderados, presenta un paisaje vegetal en el que encinas y alcornoques componen el estrato arbóreo. Los deslindes de la dehesa del Puerto de Carmonita y las dehesas de Mayoralgo y Mayoralguillo son ilustrativos. El aumento de la pluviosidad ofrece mejores condiciones al alcornoque, que encuentra condiciones óptimas para su desarrollo. Esto permite que encinas y alcornoques alcancen un equilibrio. El deslinde de $1457^{112}$ presenta diez encinas, un carrasco y una alusión a

\footnotetext{
${ }^{108}$ AMP, Libro de las Moxoneras, fols. 22 r. -25 v.

${ }^{109}$ AMP, Libro de las Moxoneras, fols. 29 r. -32 v.

${ }^{110} \mathrm{AMT}$, Leg. 6, n ${ }^{0} 1$, fols. $12 \mathrm{r} .-13 \mathrm{r}$.

"'En 1515 Juan Jiménez, vecino de Santa Cruz (aldea situada en la Sierra de Santa Cruz, cuenca del Guadiana, proxima a las localidades citadas) pide permiso para cortar madera de roble para una casa; se le concede en el Robledo, en Berzocana (AMT, Leg. 3, $n^{\circ} 2.1$, fol. 143

${ }^{112}$ Floriano. Ibid., doc. 103.
} r.) 
encinas en general frente a nueve alcornoques y una moheda y una mata de esta especie; también aparece una moheda. El matorral de brezos y escobas y el hecho de que sólo los alcornoques se presenten en masas compactas nos permiten suponer que la encina ha ganado peso merced a una tala selectiva. El deslinde citado entre Talavera la Vieja-Alija y Talavera de la Reina presenta un posible dominio del alcornoque cuando, dejando atrás la zona más próxima al Tajo, pasamos a espacios más elevados, al noreste de Fresnedoso de Ibor ${ }^{113}$

Las estribaciones montañosas que superan holgadamente los seiscientos metros y en los que la pluviometría aumenta considerablemente presentan un estrato arbóreo diferente. La encina pierde terreno, mientras el alcornoque se transforma en el arbol dominante en competencia con robles y quejigos. Estas dos especies sólo encuentran cabida en las zonas más elevadas. La actuación humana parece fundamental para explicar ciertas realidades que se contraponen al paisaje que debieron conocer los repobladores. El Libro de daños en los montes de Trujillo nos muestra como en Robledillo el predominio de los alcornoques (treinta y dos) parece claro sobre otras especies vegetales (una encina). La información más pobre que ofrece sobre Ibahernando o, ya en el Guadiana, sobre Santa Cruz de la Sierra o Puerto de Santa Cruz, muestra un mayor equilibrio entre ambas especies. El caso de Robledillo parece ilustrativo. El claro predominio de los alcornoques parece consecuencia de la mayor pluviometría. Sin embargo, esta realidad contrasta con un topónimo que algún siglo antes debió responder a la realidad paisajística. Al igual que frente a la encina la actuación humana perjudica al alcornoque, éste parece beneficiarse frente al roble o el quejigo.

En la zona de Cabañas, robles y alcornoques componen el paisaje arbóreo $^{114}$. Garciaz y Berzocana, bastante bien documentados, permiten ahondar en los detalles. El clímax de estos espacios corresponde al alcornoque y al roble, como refleja la toponimia. No aparece ningún topónimo relativo a la encina, debido a su papel de mero acompañamiento. En los espacios menos elevados o más abiertos, el alcornoque, acompañado

\footnotetext{
${ }^{113}$ Se cita un alcornoque seco y otro grande, lo que contrasta con la zona más próxima al Tajo (AHPC, Ayunt. de Talavera la Vieja, reg. 1, fol. 17 v.).

${ }^{114} \mathrm{AHN}$, Secc. Nobleza, Frías, caja 1246 (contamos con la realización de la mojonera entre Deleitosa y Cabañas, anterior a 1493, y con un tardío amojonamiento de 1562 de la cañada que pasa por este lugar).
} 
por la encina, se convierte en el arbol dominante, papel que cede en los lugares más cerrados y elevados al roble.

El alconoque ejerce su dominio en la zona que se extiende al norte de Garciaz, en la cuenca del río del mismo nombre y en la confluencia de éste con el río Hornia, en un espacio cuya altura se sitúa fundamentalmente entre los quinientos y los ochocientos metros y en donde se ubican las heredades, dehesas o montes de Tejadilla (actualmente en el término de Madroñera), Mohedas, Las Hoyas, Valdelaspuercas, El Alijar, Agudo, La Hornia y La Buitrera. El roble no esta ausente ${ }^{115}$, pero parece cumplir un papel secundario frente al alcornoque y la encina. Junto a topónimos que delatan su predominio, el alcornoque no deja de aparecer en formaciones vegetales densas en donde es dominante o exclusivo. Se documenta la cuesta del alcornocal espeso (posiblemente respondiendo al estado de la vegetación) en 1353 y el alcornocal en 1384, en los límites entre Mohedas, Las Hoyas y Valvellido, con alturas máximas que superan ligeramente los setecientos metros $^{116}$. El deslinde del alijar de Garciaz y la heredad de Tejadilla ${ }^{117}$, espacios situados muy cerca de la confluencia de los terminos municipales de Garciaz, Madroñera y Aldeacentenera y con alturas entre seiscientos y ochocientos metros, es el que más datos nos ofrece sobre vegetación. El alcornoque es el arbol dominante $(75 \%)$ frente a la encina $(25 \%)$.

Los lugares más elevados o que por la orientación de su relieve disfrutan de una mayor pluviometría, presentan un mayor peso del roble melojo o rebollo. En la cuenca del río Valbellido, que con orientación nortesur en líneas generales discurre entre los términos de Garciaz y Berzocana y que al norte de la actual Umbría del Oso forma un valle estrecho delimitado por alturas que alcanzan o se acercan a los mil metros, el roble, que da origen al topónimo Robledo, es prácticamente la única especie vegetal en la cuenca alta y media. En el amojonamiento de la dehesa de Valvellido de 1511 se puede apreciar como en un espacio comprendido entre los topónimos actuales Cuerda de la Mata del Oso, Cerro de la Cardosa y Cerro Valdesordillo, con alturas que alcanzan los novecientos metros, se desarrolla

\footnotetext{
${ }^{115}$ AMT, leg. $5, n^{0} 19$, fols. 9 r. -9 v. (deslinde de la dehesa de Valdelaspuercas con la caballería de La Hornia).

"AMT, leg. 1, n" 1, fols. 14 v. y 22 v.

${ }^{117}$ AMT, leg. 3, no 1, fols. 139 r., 141 r.-142 v. y 145 v.
} 
un paisaje vegetal sobre cuyas características no ofrecen dudas los 49 robles citados $(100 \%)^{118}$.

El Libro de daños en los montes nos informa de la importancia creciente, quizás sobrevalorada, de la encina. El ejemplo de Garciaz es ilustrativo: aparecen citados trescientos setenta robles, ciento doce encinas, veintidós carrascos, veintitrés alcornoques y cien encinas y alcornoques. El roble aparece en menciones que afectan a un elevado número de arboles (trescientos dieciocho, cuarenta y cuatro), lo que no sucede para la encina, el alcornoque o los carrascos. En cualquier caso, estamos ante un desarrollo importante de la encina, que contrasta con lo que parece el clímax de la zona. El roble parece reducido a lugares con intenso arbolado pero muy concentrados espacialmente. Las treinta encinas que aparecen citadas en la heredad de Tejadilla ${ }^{119}$ nos permiten intuir que esta especie se ha desarrollado en zonas de antiguo dominio del alcornoque y no tanto en espacios en que el clímax corresponde al rebollo. En Berzocana la misma fuente también nos permite documentar el gran desarrollo de las encinas (doscientas setenta, frente a cuarenta y dos alcornoques y diez más un número indeterminado de robles). La importancia creciente de la encina no sería ajena a la actuación humana. Es muy sintomático sobre este aspecto que en Berzocana sólo documentemos permisos para talar robles ${ }^{120}$.

Los árboles y arbustos que acompañan a las quercíneas en las zonas montañosas se caracterizan por su escasez. Los castaños han debido sufrir un claro receso. Solo se les menciona en las ordenanzas de Valencia de Alcántara, en la avenencia realizada sobre la Parrilla y Helechoso, espacios situados entre Campillo de Deleitosa e Higuera, en una zona abrupta con alturas entre seiscientos y ochocientos metros, y en la dehesa del Robledo, en Montánchez ${ }^{121}$. Madroños y acehuches acompañan a robles, quejigos y alcornoques. El madroño aparece en los mojones que separan los términos

\footnotetext{
${ }^{118} \mathrm{AMT}$, leg. 10, $\mathrm{n}^{\mathrm{0}} 3$, fols. 1 v. $-3 \mathrm{v}$.

${ }^{119} \mathrm{AMT}$, leg. 10, n⿳0 5, fol. $163 \mathrm{v}$.

${ }^{120} \mathrm{AMT}$, leg. $3, \mathrm{n}^{\circ} 2.1$, fol. $182 \mathrm{v}$.; la autorización concedida en 1515 para cortar madera de roble en el Robledo posiblemente aluda al espacio del mismo nombre en Berzocana (Fol. 143 r.). No se documenta tala de encinas o alcornoques en Berzocana pese a documentarse en Plasenzuela, Santa Cruz de la Sierra o Logrosán.

${ }^{121} \mathrm{AHN}$, secc. Nobleza, Frías, caja 1246, fol. 14 r. del documento; AHN, Ord. Milit., libro 1103-c, p. 185
} 
de Trujillo y Montánchez ${ }^{122}$. El acehuche, asociado al lentisco, también se desarrolla en estos lugares no afectándole de modo sensible la umbría dada la suavidad de los relieves montañosos de orientación este/oeste. Pese a ello, se sitúa en ocasiones en los mismos puertos (Puerto de Albocar o Media Cacha, en la Sierra de San Pedro) o cerca de ellos (Puerto del Burro) ${ }^{123}$. El galapero aparece asociado a encinas y alcornoques en la sierra de San Pedro $^{124}$. Al igual que en la penillanura, esta vegetación asociada a las quercíneas parece tener una presencia testimonial.

\subsection{Formas de degradación: el matorral}

La actividad humana produce consecuencias indeseadas en una paisaje adehesado en el que el dominio de las quercíneas es indiscutido. De este fenómeno, nuestro conocimiento es menos preciso, pues la vegetación arbustiva atrae mucho menos la atención en los amojonamientos. En cualquier caso, las informaciones que podemos obtener de ordenanzas y deslindes nos permiten abordar las características del matorral y su vinculación con las formas de aprovechamiento y explotación de un espacio pecuario como la dehesa.

Frente a la casi desaparición de los árboles y arbustos que acompañan a las quercíneas en el bosque mediterráneo, el matorral no palatable, indicador de grados diversos de degradación, encuentra un elevado desarrollo debido a dos factores importantes: el uso reiterado del fuego y la presión ganadera. Sobre el primer elemento es sintomático que en nuestra zona de estudio los pinares, indicadores de incendios con intervalos grandes $^{125}$, encuentren un escaso desarrollo. Este hecho explica que no dejen de aparecer en nuestra documentación árboles y espacios quema-

\footnotetext{
${ }^{12}$ AMT, leg. $6, n^{\circ} 1$, fols. 12 v.-13 r. ("otro mojon grande que estava junto con unas peñas grandes e cabe un madroño e de la otra parte de las dichas peñas estan çiertos alcornoques"). Aparece una referencia a "una madronnera grande" en la penillanura cerca de la iglesia de Altagraçia en la confluencia de los terminos de Arroyo de la Luz, Cáceres, Navas del Madroño y Garrovillas, aprovechando quizás unas pequeñas elevaciones (GARCía OLIVA, Documentación, doc. 88).

${ }^{123}$ AMT, leg. $6, \mathrm{n}^{0} 1$, fols. 10 v. y 12 v. $-13 \mathrm{r}$.

${ }^{124}$ Floriano, Ibid., doc. 103.

12.5. M. Montoya Oliver, Pastoralismo mediterráneo, pp. 54-55.
} 
$\operatorname{dos}^{126}$. El fuego es utilizado habitualmente para la eliminación del matorral no palatable y para realizar rozas ${ }^{127}$. Especies como las jaras, las retamas o la torvisca indican su utilización frecuente ${ }^{128}$.

Las formas de degradación habían alcanzado un alto desarrollo a finales de la Edad Media y comienzos de la Moderna. Fernando Colón precisa el predominio de jarales o su asociación con quercíneas en seis trayectos ${ }^{129}$. Más importante que el número es que estamos ante espacios en que las formas elevadas de degradación se asientan sobre espacios considerables con o sin estrato arbóreo.

El matorral de degradación mediterráneo que aparece en la documentación es muy variado. Sin embargo, no todas las especies alcanzan importancia ni se presentan del mismo modo. El aspecto más llamativo es la amplia difusión de las jaras; en el espacio climácico del alcornoque, el roble o el quejigo, también adquiere relevancia el brezo. La coscoja debió tener una gran importancia en el término de Cáceres, pero aparece poco en la documentación ${ }^{130}$.

En relación con las jaras, es posible que, dada su tendencia a formaciones cerradas y homogéneas, estén sobrerrepresentadas en la documentación, pues parte de nuestra información tiene un carácter general $\mathrm{y}$ alude a este tipo de formaciones, y no a otras especies que se presentan de modo más disperso. De todos modos, los jarales serían la manifestación más llamativa e importante de las formas de degradación. Las jaras representan un grado elevado de degradación y su desarrollo, como especie colonizadora, esta vinculada al uso reiterado del fuego. La variedad de cistáceas permite su desarrollo tanto en la penillanura como en los espacios montañosos.

\footnotetext{
${ }^{126}$ AMP, Libro de las Moxoneras, fols. 29 v y 93 v; García Oliva Documentación, doc. 167, p. 320; AMT, leg. $10, \mathrm{n}^{\circ} 3$, fols. 2 v. -3 r.

127 "ninguna persona de ningund estado e condiçion que sea no sea osado de poner fuego en ningund tienpo en los exidos e alixares e cavallerias de la dicha çibdad e sus terminos e lugares salvo sy no fuere en su propia dehesa o heredad o barvecho que tenga propia suya o de renta... que no sea antes de Santa Maria de agosto" (SÁNCHEZ RubIO, Documentación, III, p. 47); en un sentido parecido, BOIIÓRQUEZ, Ibid., pp. 150-151

${ }^{128} \mathrm{Cf}$. nota 53; J.M. MONTOYA OLIVER, Encinas y encinares, pp. 75-76; J.M. LlORENTE PINTO, Los paisajes adehesados salmantinos, Salamanca, 1985, pp. 129-131.

${ }^{129} \mathrm{~F}$. COLÓN, Ibid., I, pp. 122, 177, 193 y 221; II, pp. 93 у 294.

${ }^{131}$ García Oliva, Documentación, doc. 76, 149 y 199 ("en el termino desa dicha villa ay mucha coscoja de que se saca mucha grana"); en el término de Alcántara, cerca del límite con Arroyo de la Luz, antigua aldea cacereña, unos vecinos de Brozas "hallaron a uno del Casar de Caçeres que andava cogiendo grana" (AMAL, leg. $625, \mathrm{n}^{\circ} 1$, fol. 73 r.).
} 
Frecuentemente estamos ante formaciones compactas que llaman la atención de Fernando Colón y de las ordenanzas municipales. En Valencia de Alcántara, los jarales son la única formación vegetal que se menciona de modo sistemático junto a los montes espesos y bravos ${ }^{131}$. En Trujillo sólo se alude a ellos de modo genérico ${ }^{132}$. En el término de Cáceres debían tener un gran importancia. Tres de los trayectos descritos por Fernando Colón en donde predominan estas formaciones vegetales transcurren total o parcialmente por su término. Además, en la Sierra de San Pedro dominan espacios muy importantes que dan origen al topónimo jara, en los que el ganado no encuentra fuentes de subsistencia. Estos terrenos se intenta recuperar mediante normativas que incentivan su roturación en condiciones ventajosas ${ }^{133}$. Entre Alcántara y Arroyo de la Luz aparecen en formaciones homogéneas o mezcladas con otras especies como romero, lentisco, brezo y madroño ${ }^{134}$ En la antigua tierra de Plasencia, los jarales y jaras aparecen, sin ninguna duda, como el matorral más abundante. En la dehesa de las Quebradas se señala que "ay muchos e bravos montes de xara". Aparecen otras muchas referencias concretas a formaciones compactas o a formas más dispersas. Se mencionan en Riofrío, el baldío de Helechoso, la dehesa de Saucedilla de la Casas o la de Las Quebradas ${ }^{135}$.

Las retamas y los brezos se caracterizan por una menor difusión y, sobre todo las primeras, por su aparición en formas menos densas. Las retamas, una manifestación de ligera degradación en el encinar, pueden presentarse en formaciones cerradas (se alude a un "çerrillo de retamas" cerca de Casillas en el Berrocal trujillano), pero mucho más frecuentemente aparecen de modo aislado. Así lo hacen en el Berrocal de Trujillo, en los

\footnotetext{
${ }^{131}$ BoHÓRQUEZ, Ibid., pp. 93 (“xarales e sierras e montes bravos"), 128 (“montes bravos de xarales y otros montes espesos y bravos que en las çafras oviere"), y 132 ("sierras y xarales y montes bravos"); igualmente, pp. 124 y 234.

${ }^{132}$ SÁnchez Rubio, Documentación, III, p. 76.

${ }^{133} \mathrm{La}$ Jara se define como "lugar donde no puedan entrar ganados ovejunos a paçer en el tal monte"; el terreno roturado en este espacio se puede aprovechar individualmente durante cinco años, después de lo cual "sea raso e desmontado en que se paçienten los ganados de los vezinos. desta villa e de su tierra" (GARCía Oliva, Documentación, docs. 122, rub. 8, y 134).

${ }^{134} \mathrm{AMAL}$, leg. $625, \mathrm{n}^{\circ} 1$, fols. 37 v. ("un altoçano de lentisco e romero e xara pequeño"; "un mogote de xaras e romero e breço e lentisco"), $38 \mathrm{r}$. ("unas madroñeras e xaras"), $55 \mathrm{r}$., 64 r. ("xaras e madroño e breço e lentisco"), 74 v. ("çerro pequeño montoso de xaral e madroño") y $76 r$.

${ }^{135}$ AMP, Libro de las Moxoneras, fols. 25 r. y 31 v.; ACP, leg. 138, $n^{\circ} 2$, fol. 20 r., y leg. $1, n^{\circ} 39$, fols. 21 v. y 29 v.
} 
ejidos de Cáceres, entre Alcántara y Arroyo de la Luz, o en la dehesa de Las Quebradas. No sería rara su presencia en espacios con cierto aprovechamiento agrario ${ }^{136}$.

Los brezos oscilan entre presentarse en formaciones cerradas o de forma aislada, pero siempre ligados a los lugares de mayor pluviometría. Se documentan en "la falda de la sierra" en Valencia de Alcántara, en el deslinde de las dehesas del Puerto de Carmonita y Mayoralgo y Mayoralguillo, donde se citan también "unas escobas", y alrededor de un mojon en Helechoso (Deleitosa), mezclados con jaras; también aparecen en los suaves relieves que delimitan las villas de Alcántara y Arroyo de la Luz ${ }^{137}$.

Otras especies debieron tener un menor desarrollo. La torvisca se presenta de modo aislado, preferentemente al lado de encinas o alcornoques, $o$ en su defecto de algún otro arbusto ${ }^{138}$. En el Berrocal de Trujillo se documentan en 1493 dos cañadas gamonosas y "un çerro llano tomelloso" ${ }^{139}$. Entre Alcántara y Arroyo de la Luz, el romero aparece asociado al lentisco, la jara y el brezo ${ }^{140}$. Las escobas parecen sustituir a las retamas en la Sierra de San Pedro ${ }^{141}$. Sin duda, esta visión tan fragmentaria que presentamos del matorral de degradación tiene mucho que ver con nuestras fuentes más preocupadas, en cuanto fuente de recursos o como referencia espacial, por el estrato arbóreo.

\subsection{La vegetación de ribera}

La vegetación de ribera ha sufrido un receso claro en el periodo bajomedieval. Sin duda, esta realidad aparece como una de las más claras manifestaciones de la actuación humana sobre el medio natural. Hay dos

\footnotetext{
${ }^{136}$ AMT, leg. 3, nº 1, fols. 272 v., 392 r., 400 r. y 408 r.; García Oliva, Documentación, doc. 76; AMAL, leg. $625, n^{\circ}$, fol. 6 r. y 62 v.; ACP, leg. $1, n^{\circ} 39$, fol. 30 r.; en las Ordenanzas de Valencia de Alcántara se alude a barbechos con retamas y escobas (BOIÓRQUEZ, Ibíd., pp. 98-99).

${ }^{137}$ BoHÓRQUEZ, Ibid., pp. 163; más referencias a brezos o brezales en pp. 124 y 234-235; FLORIANO, Ibid., doc. 103; AMP, Libro de las Moxoneras, fol. 29 r.; cf. nota 134.

${ }^{138}$ En el baldío de Brezalejos aparecen dos encinas con torviscas bajo su copa (AMP, Libro de las Moxoneras, fol. $98 \mathrm{v}$.); en Trujillo se citan junto a un alcornoque y una retama (AMT, leg. $3, \mathrm{n}^{\circ} 1$, fols. 145 v. y 400 r.). Este comportamiento es habitual en esta especie: J.M. Llorente PINTO, Ibid., p. 131.

${ }^{139} \mathrm{AMT}$, leg. 3, n⿳0 1, fols. 394 r., 411 v. -412 r. y 418 v.

${ }^{1+10} \mathrm{AMAL}$, leg. 625, $\mathrm{n}^{\circ} 1$, fol. $37 \mathrm{v}$.

${ }^{1+1}$ FLORIANO. Ibíd. doc. 103.
} 
elementos que afectan negativamente a las especies ribereñas. Por un lado, no pueden competir con las quercíneas en una explotación integral del arbolado. Por otro, ocupan algunos de los espacios de mayor interés productivo $^{1+2}$. De este modo, las saucedas, alisedas y fresnedas que debieron encontrar los repobladores en los siglos XII y XIII han desaparecido a finales del siglo $\mathrm{XV}$.

Sólo en Valencia de Alcántara parece haber cierta cantidad de fresnos. Sin duda, esto se debe a la existencia de un paisaje vegetal en un estado de conservación relativamente bueno. Sin embargo, las penas establecidas para su protección y las normativas existentes para la obtención de su madera ${ }^{143}$ muestran un interés limitado en su conservación. Su protección se debe sobre todo a la necesidad de madera; la utilización de su ramón sería subsidiaria.

La desaparición de los bosques de ribera es algo que no ofrece dudas. Hay que considerar que un número importante de mojones se sitúan muy próximos o junto a corrientes de agua; en otros casos, más numerosos, esa proximidad se intuye sin que pueda constatarse con total seguridad. En cualquier caso, los espacios ribereños están suficientemente representados en los deslindes, no así sus formaciones vegetales permanentes. En nuestra documentación sólo aparecen una aliseda en el Tajo, un fresno en las ordenanzas del monte de Cáceres, y un aliso en la Mata de Gibranzos ${ }^{144}$. El primero se ubica "en mitad del rio, frontero de un azauche"; el segundo es "un aliçaçe viejo". Frente a esta escasa presencia de la vegetación arbórea de ribera, las referencias a formas de degradación son más numerosas, pese a que las fuentes sólo excepcionalmente aluden a las especies arbustivas. En la Mata de Gibranzos, en plena penillanura, aparecen unos helechos y unas zarzas gordas junto al arroyo del Pinarejo; unas junqueras se documentan junto a un pozo en el camino de Cáceres a Montánchez; y un juncal, en los

\footnotetext{
p. 159

${ }^{1+2}$ C. Ferreras y Ma E. Arocena, Guía fisica de España. 2. Los bosques, Madrid, 1987,

1433"persona alguna corte ni desmoche fresno alguno en los terminos desta villa, syn licençia del regimiento, so pena ... de trezientos maravedis e, sy lo desmochare del todo para bueyes y otros ganados... yncurra en pena por cada arvor, de çiento e quarenta maravedis... para madera de las casas y para los arados e timones e cosas nesçesarias a la labrança y al coger del pan, que sin liçencia y themor de la dicha pena, puedan coger e cortar todo lo que les fuere nesçesario, eçepto por el pie" (BOHÓRQUEZ, Ibíd., p. 131)

${ }^{1+4}$ AMP, Actas, a. 1522-6, fol. 348 r.; García Oliva, Documentación, doc. 122; AMT, leg. 4. $\mathrm{n}^{\circ} 3$, fol. $23 \mathrm{r}$.
} 
límites entre Talavera la Vieja-Alija y Talavera de la Reina; en el Tajo, la Orden de Alcántara posee cañales muy lucrativos (en 1502 obtiene de ellos diecisiete mil maravedís) $)^{145}$.

La eliminación de los bosques de ribera ha permitido que otras especies vegetales colonicen el terreno. El fresno citado se sitúa fuera de su lugar habitual, ocupando el espacio en el que se suelen desarrollar las saucedas, en pleno contacto con el agua e invadiendo incluso los islotes; aún más desubicado se encuentra el acehuche, especie con escasas exigencias hídricas. Al margen de este caso aislado, la documentación no nos deja de mostrar, en algunos casos con total claridad, como los espacios próximos a los cursos de agua son colonizados por especies ajenas a la vegetación de ribera. En la delimitación de la dehesa del Puerto de Carmonita y las de Mayoralgo y Mayoralguillo, aparecen "unos gadaperos pequeños çerca de un arroyo pequenno" ${ }^{146}$. Los ejemplos más abundantes los ofrece la documentación placentina. En la dehesa de La Cortilla aparece "una enzina junto al dicho arroyo de la covacha" ${ }^{147}$; en el deslinde del Brezalejo se hace referencia al "charco blanco junto al arroyo en un carrasco" ${ }^{148}$. Los ejemplos más numerosos corresponden al deslinde de la dehesa de Saucedilla de las Casas, cuyo topónimo es muy ilustrativo. Hasta seis encinas aparecen con seguridad junto a corrientes de aguas mientras que para otras dos se presentan ciertas dudas ${ }^{149}$. La tala de los bosques de ribera ha dejado libre un espacio que ha podido colonizar prioritariamente la encina; otras especies favorecidas por la humedad edáfica, como los galaperos ${ }^{150}$, encontrarían buenas condiciones para su difusión.

\footnotetext{
${ }^{145}$ SÁnchez Rubio, Documentación, I, doc. 51; AMT, leg. 4, no 3 , fols. 6 v. y 15 v.; AHPC, Ay. Talavera la Vieja, reg. 1, fol. $17 \mathrm{r}$; M.F. LADERO QUESADA, La orden de Alcántara en el siglo XV. Datos sobre su potencial militar, territorial, económico y demográfico, "En la España medieval". II (Estudios en memoria del Profesor D. Salvador de Moxó), Madrid, 1981, pp. 530-533.

${ }^{1+6}$ FlORIANO, Ibíd., doc. 103.

${ }^{147}$ AMP, deslinde de la dehesa de La Cortilla, a. 1525, fol. $24 \mathrm{r}$.; también se citan "quatro enzinas... el qual mojon esta çerca del dicho arroyo de los enxertos" (fol. 24 r.), pero en este caso no está totalmente claro la mayor o menor proximidad a la corriente de agua.

${ }^{148}$ AMP, Libro de las Moxoneras, fol. $98 \mathrm{r}$.

${ }^{1+9} \mathrm{ACP}$, leg. $38, \mathrm{n}^{0}$ 2, fols. 31 v., 32 v., 59 r., 67 r., 68 r. y 69 v.

${ }^{150}$ J.M. LLORENTE PINTO. Ibid., p. 131
} 


\section{LA FAUNA}

Las transformaciones que se desarrollan en el siglo XV van a incidir no sólo sobre las comunidades vegetales sino también sobre la fauna salvaje. A la transformación del ecosistema vegetal se añade una mayor presión cinegética. El control de la caza será inevitable para asegurar la conservación de la fauna salvaje. Se prohibirán las artes más mortíferas a la vez que aparecen las vedas. El modelo faunístico no parece sufrir cambios drásticos en la Baja Edad Media. Los fueros nos muestran a las mismas especies que veremos en esta época y que van a permanecer en la edad moderna. Esta tendencia continuista es compatible con determinados cambios que expondremos. La actuación humana sobre el ecosistema favorece a las especies más versátiles y menos condicionadas por la influencia antrópica. Las más sensibles a la alteración del paisaje vegetal, como el oso, se verán drásticamente reducidas a zonas marginales camino de su desaparición. Las más adaptables, incluso aquellas que se intentan erradicar, como el lobo, se mantienen, sin que sus poblaciones parezcan disminuir, o aumentan.

\subsection{Una especie en receso: el oso}

El oso es un animal muy sensible a la actuación humana. Intenta mantenerse alejado de los centros de hábitat y puede definirse como un animal de clara vocación forestal y de montaña. Por todo ello, procesos como la roturación, con la consiguiente transformación del paisaje vegetal, y la creciente ocupación humana le influyen poderosamente. La geografía del oso es una manifestación en negativo del grado de transformación al que un territorio determinado ha sido sometido por el hombre ${ }^{151}$.

La información que tenemos sobre el oso tiene un importante sesgo cronológico. Procede, sobre todo, del Libro de la Montería de Alfonso XI. A través de él podemos hacernos una idea cabal de su comportamiento y distribución espacial a mediados del siglo XIV, cuando se ha materializado el proceso de repoblación previo a la crisis bajomedieval.

El oso, a mediados del XIV, sólo aparece en espacios limitados (mapa 2). En la mayor parte de la vertiente meridional del Tajo ha desaparecido totalmente. Como se llega a precisar incluso la aparición

\footnotetext{
${ }^{151}$ V. CLEMENT, Ibid., p. 92.
} 
ocasional, podemos estar seguros de su completa desaparición en los lugares en los que no se le menciona. Las tierras alcantarinas situadas al sur del Tajo y el concejo de Cáceres no albergan poblaciones de ursidos. Incluso las zonas elevadas y aún con densa vegetación de Valencia de Alcántara los han visto desaparecer a mediados del XIV. Las zonas de llanura de todo el territorio los han expulsado con la excepción de Garrovillas, donde aparecen sólo ocasionalmente ${ }^{152}$. El oso sólo ocupa territorios residuales próximos a la divisoria de aguas entre el Tajo y el Guadiana que se caracterizan por su orografía accidentada. En su mayor parte están por encima de los 600 metros. Esto explica que no aparezcan en la Sierra de San Pedro, sujeta por la relativa suavidad de sus relieves a una intensa explotación ganadera.

La geografía del oso forma una especie de $\mathrm{V}$ caída en la zona oriental. Su mayor implantación se sitúa entre Montánchez y la cuenca del Viejas, en el límite ya con el concejo de Talavera; luego podemos trazar una línea hasta Miravete, donde, sin embargo, sólo aparece en sus extremos. La única excepción a la $V$ señalada es Garrovillas, población cercana al Tajo y a Ceclavín, en donde el oso habita a lo largo de todo el año. Las dos zonas de mayor ocupación se sitúan entre Robledillo-Villamesías-Santa Cruz, donde son más abundantes en la solana, es decir, ya en la cuenca del Guadiana, en el alto Búrdalo, y rodeando la cuenca del Viejas, en el límite entre Guadalupe y el concejo de Talavera, en las cuencas de los ríos Ibor y Guadalupejo.

Hay un elemento del mayor interés. El Libro de la Montería nos informa sobre el tiempo que los osos ocupaban los diversos bosques. Esta información nos lleva a otro campo, la ecología del oso. En la vertiente meridional del Tajo, al margen de los espacios en que aparece ocasionalmente (Garrovillas y ladera de Miravete), hay un predominio del invierno como estación osera (Torre de Sta María, Madroñera, Valle y Garganta del Viejas); nunca aparecen sólo en verano, mientras que lo hacen a lo largo de todo el año en el alcornocal de Montánchez, Valcerrado (Robledillo de Trujillo) y Garciaz (El Robledo); el monte de los colmenarejos ${ }^{153}$ lo

\footnotetext{
${ }^{152}$ Los osos no parecen ocupar los abruptos riberos del Tajo, sino la zona situada al sur de Garrovillas, entre este lugar, la Cabeza de Araya y el camino del Casar de Cáceres ("Et es la voceria en el camino que viene del Casar para las Garroviellas. Et es el armada escontra la Cabeza de Araya sobre el camino que va para las Garroviellas": Libro de la Montería, p. 256).

${ }^{153}$ Se cita entre la ladera de Miravete y la Jara de Jaraicejo; ante se ha citado el monte de Santa Ana, ubicado al este de Almaraz; posiblemente este monte estaría situado entre Miravete y Jaraicejo, dada la tendencia a agrupar los montes por zonas (en el mismo epígrafe casi todos
} 
ocupan en invierno y "en tiempo de las colmenas". Esta realidad entra en consonancia con un animal no territorial que se desplaza frecuentemente ${ }^{154}$. La busqueda de alimentos produce desplazamientos sujetos a una cierta estacionalidad. Es llamativo que mientras en la vertiente meridional del Tajo el oso aparece sobre todo en invierno, no sucede así por ejemplo en el valle del Jerte, donde es mas abundante en verano.

La explicación de este fenómeno creemos que está sujeta a la provisión de alimentos. No nos falta información sobre su busqueda, pues a veces al lado de la estación se cita algún otro aspecto relacionado con ella. De este modo, se menciona la relación entre los osos y la bellota, las uvas y las colmenas, campos en los que establece una competencia con el hombre. Es llamativa la relación con la miel, sin duda, uno de las aspectos más conflictivos ${ }^{155}$. No es casual que aparezcan en el monte de los colmenarejos en el tiempo de las colmenas. Es llamativo que en los valles de Garciaz y en el Berrocal de Burdalo aparezcan sendos topónimos relacionados con este sector ${ }^{156}$. Por otro lado, y en general, las zonas de ocupación del oso, poco agrarizadas y con una importante vegetación natural, son zonas potenciales de actividad colmenera.

Junto a la miel, la bellota constituye otro alimento importante para el oso. La proliferación de dehesas debido a la explotación pecuaria ofrecía un territorio en donde en otoño y principios de invierno la alimentación era abundante.

Generalmente se mencionan sólo dos estaciones, el invierno y el verano, siendo raro en nuestra región que se mencionen otras. De este modo, otoño y primavera se subsumirían en las dos citadas. El predominio del oso en invierno está en clara conexión con la disponibilidad de alimentos, ya sean éstos producidos o recolectados preferentemente por el hombre o

los montes citados están proximos al que aparece antes y después). M. TERRÓN ALBARRÁN, De la Extremadura agreste: notas para un estudio de la evolución histórica de la fauna de caza mayor, "La caza en Extremadura", Cáceres, 1987, p. 39, no lo sitúa, ni aparece este topónimo en la hoja del mapa topográfico nacional correspondiente a Jaraicejo.

${ }^{154}$ En 1988 un oso radiocontrolado en Riaño se movió sobre un espacio de $1308 \mathrm{~km}^{2}$ (A. Clevenger y F. Purroy, Ecología del oso pardo en España, Madrid, 1991, p. 55).

${ }^{155}$ Es una constante. Los daños producidos por el oso en Palencia afectan a colmenas $(67,7 \%)$, bóvidos $(16,1)$, cabras y ovejas $(15,3)$ y equidos $(0,8)$ (Ibíd., 125-126).

${ }^{156}$ Libro de la Montería, pp. 242-243; hay más ejemplos en los que se menciona explícitamente esta relación oso-colmenas: Ibíd., pp. 248 (Nava del Mellado, en Capilla), 263 (Arroyo de Corcheros, cerca de Montemolín) y 264 (Castillo de Culebres y Arroyo del Moro). 
silvestres, que no se mencionan en cuanto no son directamente de interés humano. Mientras la actividad colmenera se desarrolla entre primavera y otoño, la bellota está disponible desde setiembre-octubre hasta enero, previo al periodo de hibernación que debía ser muy limitado. La disminución de las temperaturas y las lluvias permitirían el crecimiento y/o disfrute de la vegetación herbácea entre octubre y junio. La bellota, la vegetación herbácea y los frutos silvestres se dispondrían en nuestro territorio preferentemente entre octubre y finales de la primavera.

De este modo, creemos que se explica la preferencia invernal que presenta el oso en nuestro territorio. La disponibilidad de miel a lo largo del verano no compensa la disminución de otros alimentos, al margen de que la visita a las colmenas no esta libre de riesgos. Menos claro son las causas por la que algunos hábitats albergan osos sólo en invierno y otros en todas las estaciones. En algunos casos, adivinamos las razones. Se trata de lugares con elevada pluviometría en donde, unido al descenso término que produce la altura, el agostamiento de la vegetación herbácea sería más tardío. En Guadalupe (1.0001 mm.) aparecen preferentemente en verano; Montánchez está situado en uno de los puntos más elevados; también se caracteriza por una elevada pluviometría el espacio entre Garciaz $(768 \mathrm{~mm}$.) y Berzocana (1038 mm.). Menos claras serían las razones para el monte de Valcerrado, en Robledillo $(718 \mathrm{~mm}$.), que quizás se vea favorecido por la dirección Norte-Sur del relieve; en los colmenarejos, que también estaría situado en una zona abrupta, las colmenas parecen explicar la presencia veraniega, como se señala explícitamente. De todos modos, otros lugares que sólo ocupan en invierno tendrían una situación muy similar (cuenca del Ibor o relieves entre Montánchez y Santa Cruz). Es posible que en las diversas comarcas los osos eligieran las espacios que ofrecieran mejores condiciones sin verse obligados a realizar grandes trayectos. De ser así, las zonas que ocuparían en verano y en invierno no estarían distantes.

La escasez de bosques naturales obliga al oso a ocupar espacios donde llega la actividad humana. En algunos casos se nos indica que estamos ante bosques aclarados. El bosque de Madroñera "es monte tendido, et es encinar por o puede andar home de caballo"; el monte de los valles de Garciaz es "muy bueno de andar"157. Los espacios con colmenas también nos ilustran sobre los lugares preferidos por los osos. Estos espacios

\footnotetext{
${ }^{157}$ Libro de la Montería, pp. 242-243.
} 

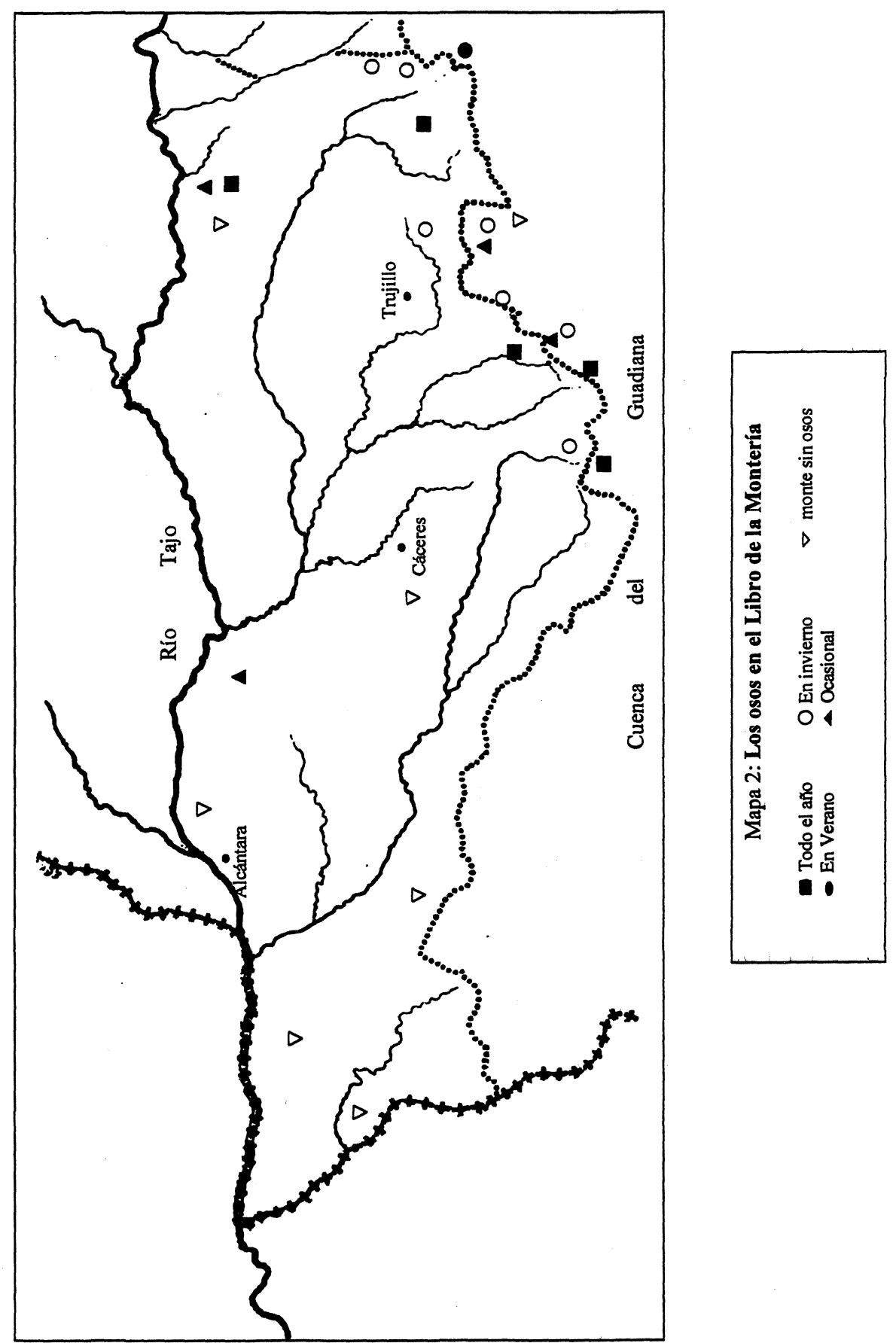
debemos imaginárnoslos con abundancia de plantas melíferas como retamas, tomillos, romero, también encinas. El matorral sería seguramente predominante.

Al margen del Libro de la Montería, la información que tenemos sobre los osos es prácticamente nula. Bien es verdad que, de no ser por esta obra cinegética, también sería inexistente para el siglo XIV. La escasa información que tenemos sobre este animal debemos considerarla en relación con sus exigencias ecológicas. Siendo menos abundante que el lobo y de vocación claramente forestal, resiste mucho menos la humanización del paisaje. Su contacto con el hombre es menor y los daños que puede ocasionar, considerablemente inferiores. No se plantea, por tanto, entre el oso y el hombre una clara competencia por el espacio. Por ello no aparece mencionado en las ordenanzas. Además, no es objeto de caza por parte de los no nobles, que no verían en su carne suficiente atractivo ${ }^{158}$; tampoco se gratifica su captura, pues habitan los lugares mas escabrosas y nunca son demasiado numerosos. De todos modos, que por parte de los colmeneros no tengamos información sobre daños en la Baja Edad Media parece un indicio de su disminución. Sólo se les menciona en el acuerdo de vecindad sellado en 1482 entre Cáceres, que no debía contar con poblaciones de úrsidos, y Montánchez $^{159}$. La población de osos se considera propiedad particular de cada concejo, al igual que los venados o los jabalíes, y sólo los vecinos pueden cazarlos. No se mencionan de modo explícito en el acuerdo de vecindad entre Trujillo y Cáceres de $1485^{1(x)}$, si bien, las zonas oseras de Trujillo están muy distantes de los límites con el concejo cacereño. En el siglo XVI aparecen por los lugares que cita el Libro de la Montería: sierra de Guadalupe, Ibores, "desde la cabecera de Cáceres hasta las asperas cordilleras de Herrera del Duque" 161 .

\footnotetext{
${ }^{15 x}$ Bartolomeo Platina en una manual italiano de dietética toma en consideración esta carne, aunque se advierte que es "pesada de digerir" (B. ANDREOLLI, L'orso nella cultura nobiliare dall'Historia Augusta a Chrétien de Troyes, "Il bosco nel Medioevo", p. 47).

15\%". qualquier persona que... entrare a caçar o ballestear del un termino al otro a caça de venados, o puercos o osos" (GARCí OLIVA, Documentación, doc. 20, p. 38).

I(n)SÁncliez RubIo, Documentación, I, doc. 96 (se mencionan "perdizes, o conejos, o venados o pescado"; el termino venado designa tanto al ciervo como a la caza mayor en general).

16!M. TerRón AlbarRán, Ibíd., p. 47.
} 
El oso no ha desaparecido a finales de la Edad Media de la vertiente meridional del Tajo, pero todo apunta a su carácter residual. Posiblemente ha sufrido un retroceso que facilita el silencio documental.

\subsection{La lucha contra un depredador: el lobo}

A finales de la Edad Media se generaliza un elemento que va a ser una constante en la época moderna y contemporánea, la lucha contra el lobo. Este conflicto en sí mismo ya entraña una importante información: al margen de la oposición entre dos superdepredadores, lobo y hombre, que no deja de manifestarse con anterioridad ${ }^{162}$, la generalización del conflicto es la manifestación más clara de los cambios que el incremento demográfico y las subsiguientes roturaciones han producido en el medio natural.

La presion sobre los recursos y el desarrollo agrario alteraron el ecosistema en que se desarrollaban los grandes herbívoros; simultáneamente, la ganadería realiza un aprovechamiento más exclusivo de las dehesas. Una manifestación del receso que debió sufrir la fauna herbívora es el mayor control que se establece sobre la caza, que ya no aparece como un bien ilimitado.

Este contexto produce un enfrentamiento abierto entre el hombre y el lobo. Este animal depende para su alimentación en gran medida de los grandes herbívoros, sensibles a los cambios ambientales; esto se une a la tentación que supone la ganadería, muy abundante en un territorio de clara vocación pecuaria en donde a la ganadería estante se añade la trashumante. Los daños producidos por los lobos debieron ser crecientes y convertirse no en algo excepcional y anécdótico sino regular. Fugazmente nos ilumina la documentación sobre este aspecto crucial. Al margen de referencias genéricas, en las cuentas municipales de Cáceres se señalan dos, veintitrés y un número indeterminado de carneros matados por los lobos ${ }^{163}$.

\footnotetext{
${ }^{162}$ R. GRande del Brio, El lobo ibérico. Biología y mitología, Madrid, 1984, pp. 206 ss.

${ }^{163} \mathrm{AMC}$, Cuentas de propios de 1519, fols. 1 v., 10 r. y 12 v.; en Valencia de Alcántara nos consta la amenaza que el lobo suponía para la ganadería: "no se vendan, ni puedan vender, carnes algunas de reses que se mueren de dolençias, ni de otras carnes dañadas salvo si fueren muertas de lobos o perniquebradas o muertas por otra ocasión" (BOIÓRQUEZ, Ibíd., p. 195) el concejo de Garciaz solicita en 1508 "quemar un pedaço de la dehesa, que esta muy montosa y reçiben mucho daño en sus ganados de lobos" (AMT, leg. 9.1, Fol. 77 v). Sobre la relación entre el descenso de la fauna salvaje y los daños producidos a la cabaña ganadera por estos cánidos: R. GRANDE DEL BRIO, Ibíd., pp. 44-5; J.C. GIL CuBILlo, El lobo. Enigmas de un depredador, Madrid, 1991, pp. 149-50.
} 
Esta lucha contra el lobo no se hace extensiva a otras especies de depredadores. Sin duda, con capacidades y hábitos alimenticios diferentes, su incidencia en la economía era muy inferior o escasa. El lince ibérico no aparece en la documentacion. Animal de poco peso, de vocación forestal y con una dieta casi exclusiva de conejos, no supone para la actividad humana un conflicto y además es muy sensible a la alteración del medio natural ${ }^{164}$. Lince y hombre viven en mundos diferentes y su competencia es a lo sumo indirecta. En cuanto al zorro, no podía faltar en la documentación, pues siendo uno de los cánidos más versátiles y que mejor se adapta a la presencia humana, es el depredador más numeroso y cercano al hombre ${ }^{165}$. Pero, por su peso, no supone un riesgo elevado para la ganadería. Sin duda, su incidencia en la actividad humana es limitada, aunque la progresiva alteración del medio va a producir la intensificación del conflicto. En la época moderna, a la lucha contra el lobo va a unirse la lucha contra el zorro. En nuestro territorio, a finales del $\mathrm{XV}$, hombre y zorro conviven sin que se paguen recompensas por su captura. Sólo en alguna ocasión documentamos el interés por evitar su proliferación en zonas cercanas a los núcleos de población ${ }^{166}$.

Sujeto a una persecución tenaz, el lobo manifiesta su versatibilidad y adaptación manteniendo sus contingentes demográficos y estando presente, con desigual densidad, en las distintas comarcas. Pasará aún mucho tiempo antes de que sea reducido a zonas marginales.

Algunos datos, lamentablemente escasos, nos ilustran sobre las características del conflicto entre la actividad humana y el lobo. En este campo, son las cuentas municipales más antiguas de finales del XV y principios del XVI las que nos ofrecen una información muy valiosa sobre las capturas, al precisar en ocasiones la fecha del pago de la recompensa y el lugar de residencia del beneficiario. Con el desarrollo de formas de

\footnotetext{
${ }^{16+} \mathrm{M}$. Delibes, Los señores del bosque en la Península Iberica, en Ch. KEMP, Los señores del bosque. Conservación del lobo, el lince, el oso y el bisonte en Europa, Barcelona, 1990 pp. 225-229.

${ }^{105}$ Los datos que tenemos para finales del siglo XVIII muestran unas población de zorros muy superior a la de lobos: en Garciaz se cazan anualmente unos cuatro lobos y treinta zorras (G. BarRientos Alfageme y M. Rodríguez Cancho, Interrogatorio de la Real Audiencia de Extremadura a finales de los tiempos modernos. Partido de Trujillo, 1966, vol. I, p. 697); en Jaraicejo, siete-ocho lobos y treinta-cuarenta zorras; en Retamosa, dos-tres lobos y ocho-diez zorras (Ibid., II, 178 y 531).

${ }^{166}$ En 1509, un vecino de Plasenzuela pide licencia "para quemar un pedaço de la dehesa que es lobera y zorrera e xaral que no fazia de perjuisio" (AMT, leg. 9, $\mathrm{n}^{\circ} 1$, fol. $11 \mathrm{r}$.).
} 
contabilidad más evolucionadas, esta información desaparece y simplemente se especifica, cuando no se incluyen en los pagos por menudo, la cantidad global desembolsada por el concejo.

Sobre el primer aspecto citado, no sabemos en ningún caso la fecha exacta de la captura, pero posiblemente no fuera muy anterior al pago de la recompensa. El tiempo transcurrido entre ambas podría muy bien ser un mes $^{167}$ o varias semanas.

Tanto en el alfoz trujillano como en el cacereño (no tenemos información del resto del territorio $)^{168}$, parece claro que las capturas de lobos están sujetas a una importante estacionalidad, que sin duda esta condicionada por la disponibilidad de alimentos. La cuentas de Cáceres muestran una coherencia total: el pico de las recompensas se sitúa en diciembre y enero (cinco lobos), continuando hasta mayo (cuatro lobos en tres libramientos entre marzo y este mes). En Trujillo, utilizando sólo las fechas referidas a lugares de la cuenca del Tajo, se satisfacen recompensas en Febrero (un lobo y una camada), mayo (un lobo y dos camadas) y agosto (una camada). Es llamativo también que en este lugar en que el año fiscal comienza el día de San Andrés (30 de noviembre), una vez que se han dejado de precisar individualmente los libramientos de lobos, se entregue a Luis de Camargo el dinero correspondiente a las cantidades satisfechas por este concepto el 13 de junio en 1511 y el 20 de mayo en $1512^{169}$.

De estos datos podemos inferir que las capturas de lobos se realizan fundamentalmente durante el invierno y principios de la primavera (diciembre-mayo), disminuyendo en el verano y otoño. Sin duda, la menor disponibilidad de alimentos en el periodo invernal les predispone a atacar presas domésticas lo que les hace más vulnerables y facilita su captura; desde mayo, el contacto con el hombre sería menor y también su incidencia en la ganadería, por lo que las capturas también disminuirían. La desigual disponibilidad de alimento a lo largo del año, por tanto, aparece como el

\footnotetext{
${ }^{167}$ Este es el tiempo que transcurre para algunos pagos, aunque no relacionados con las recompensas por lobos, en Trujillo: por ejemplo, AMT, leg. 8, fol. $145 \mathrm{v}$.

${ }^{16}{ }^{16}$ Las Cuentas de propios de Plasencia (1507-1509) (AMP) ofrecen mucha información sobre lobos pero, a principios del siglo XVI, el alfoz placentino se extendía de modo muy limitado al sur del Tajo. Nos consta el pago realizado a un vecino de Hinojal por una camada en 1509 (Fol. 34.3), pero esta captura no pudo realizarse en esta localidad, al no pertenecer a la tierra de Plasencia.

${ }^{169} \mathrm{AMT}$, Leg. 8, fol. $113 \mathrm{r}$ y $149 \mathrm{r}$; esta realidad ha sido también constatada por CiIERUBINI, Lupo e mondo rurale, en "L'Italia rurale", p. 203.
} 
elemento fundamental para explicar la relación entre el hombre y el lobo ${ }^{170}$ y nos muestra el conflicto como una consecuencia de la competencia trófica.

Dadas las limitaciones territoriales de la información, sólo podemos esbozar algunas ideas sobre su reparto espacial. En algunos casos se especifica el lugar de residencia de las personas que reciben recompensas. Hemos supuesto que hay coincidencia entre el lugar de residencia y la zona en que se ha realizado la captura. La información directamente relacionada con las villas, Cáceres y Trujillo, no es aprovechable, porque en muy pocos casos se señala la residencia en ellas, circunstancia que suponemos mucho más habitual de lo que detallan las fuentes. Por otro lado, aunque no fuera así, tampoco podríamos utilizarla. El termino estricto de estas villas, una vez sustraído el de sus aldeas, es en ambos casos demasiado amplio y abarca espacios muy diferentes. La situación de las aldeas es distinta. Con terminos pequeños, el espacio que cada una de ellas ocupa presenta características físicas más homogéneas, lo que nos permite precisar mejor cómo afectaban a estos animales condicionantes como la densidad de población, el estado de la cubierta vegetal $\mathrm{u}$ otras variables.

De los datos de que disponemos, muy escasos, puede inferirse que el lobo poblaba las diversas comarcas en su práctica totalidad. Sólo en Torreorgaz en el término de Cáceres y en Ruanes en Trujillo no se documenta la caza de ningún lobo, lo que sería poco significativo, dado que en pocas ocasiones se menciona el lugar de residencia de los beneficiarios de las recompensas. Más significativo es que las menciones aisladas se repartan con gran regularidad entre casi todas las aldeas.

En Cáceres, los lobos parecen más abundantes en Aliseda y, sobre todo, Sierra de Fuentes. Aliseda está junto a la Sierra de San Pedro y relativamente lejos de Cáceres. No conocemos su población en 1532, pues el censo de este año une su población a la del Casar de Cáceres. A finales de la Edad Media, debía ser una aldea muy poco poblada ${ }^{171}$. En su territorio se producían actos de bandolerismo. Los golfines siempre buscan zonas en donde la cubierta forestal sea abundante, como medio de buscar

\footnotetext{
${ }^{1771}$ R. GRANDE DEL BRIO, Ibid., pp. 55-59.

${ }^{17}$ En 1446. Enrique IV le concede exenciones tributarias porque "esta en lugar yermo e çerca de un puerto donde se façen muchos malos rrobos e muerte de homes... e que por ser de pocos veçinos se atreven los malfechores a fazer los dichos rrobos e muertes e daños" (FLORIANO. Ibíd., doc. 92); dichas exenciones son ratificadas en 1479 y 1480: García OLIva, Documentación, docs. 9 y 13.
} 
refugio fácil y seguro. Todo parece indicar que una escasa población y una cubierta forestal abundante son factores que permiten una mayor población de lobos.

Sierra de Fuentes sería la aldea que contaría con mayores contingentes de lobos. Mientras su extensión representa el 7,27\% de los términos de las aldeas cacereñas, las capturas de lobos representan el 17,64\%. Al igual que para Aliseda, hay dos factores que explican este hecho. Por un lado, una escasa población que en 1532 sólo alcanza 1,42 vecinos $/ \mathrm{km}^{2}$ (la menor densidad entre las aldeas cacereñas), frente a los 5,1 de Malpartida o los 3,05 de Torrequemada. Tanta importancia como esto, o posiblemente más, tienen ciertas características del término. Situado en la falda de una sierra, como su nombre indica, parte del mismo tiene un carácter abrupto y estaría entre las zonas más arboladas del alfoz de Cáceres ${ }^{172}$.

En Trujillo, los datos que tenemos presentan aspectos también interesantes. Al igual que en Cáceres, sólo las cuentas más antiguas nos informan sobre la residencia de los cazadores. Hay dos lugares, Garciaz y Berzocana, en que los lobos parecen más abundantes. Del resto de las aldeas sólo es destacable, al margen de su ya señalada amplia difusión, el caso de La Cumbre, en donde parecen haber iniciado un receso. Sobre las dos primeras aldeas contamos con una serie de datos que nos permiten evaluar el ecosistema existente. Presentan en 1531-2 la mayor densidad de población entre las aldeas trujillanas ubicadas en la cuenca del Tajo (mas de cuatro vecinos $/ \mathrm{km}^{2}$, frente a 1,88 en Ibahernando y cantidades próximas a uno o inferiores en el resto). Estas dos aldeas se asientan en terrenos relativamente abruptos, sobre todo teniendo en cuenta las características fisiográficas de la zona que estudiamos. Dentro de sus términos se alcanzan alturas superiores a los mil metros y las mismas aldeas se sitúan a 670 (Garciaz) y 728 metros (Berzocana) Por otro lado, son espacios que albergan, como hemos visto, una abundante cubierta vegetal. Estamos por tanto ante unos terminos colindantes en los que se da una importante riqueza forestal y una fuerte presión sobre los recursos que se manifiesta en la tala ilegal que se documenta en el Libro de Daños en los montes. Es posible que estemos en

\footnotetext{
${ }^{172}$ En las ordenanzas del monte de 1494 se señalan como las zonas más boscosas del termino "la sierra de San Pedro, e la sierra de Aguas Bivas, e de Mosca, e Collado e Tresquilon" (GARCÍA Oliva, Documentación, doc. 122, rub. 79). Aún a finales del siglo XVIII, "la tercera parte del termino se halla poblado de alcornoques" (G. BARRIENTOS ALFAGEME y $\mathrm{M}$. RODRÍGUEZ CANCHO, Interrogatorio de la Real Audiencia de Extremadura a finales de los tiempos modernos. Partido de Cáceres, Badajoz, 1996, p. 248).
} 
una zona con una importante población de lobos a los que afecta una creciente humanización del paisaje. En este caso, la elevada población, como alteradora del espacio, puede explicar la frecuente aparición de estos animales.

En La Cumbre, la única mención a la captura de una camada se contrapone a un termino que representa el 83,3\% del de Garciaz. Quizás esto tenga que ver con una pobre cubierta forestal. En el reparto de leña realizado en 1482 en Trujillo, La Cumbre contribuye con cuarenta cargas pese a tener un termino de $114,43 \mathrm{~km}^{2}$; Plasenzuela, aldea limítrofe, lo hace con 30 pese a contar sólo con $37 \mathrm{~km}^{2}$. Los escasez de datos nos hacen ser cautos, pero todo nos hace pensar que en esta aldea $\left(0,94\right.$ vecinos $/ \mathrm{km}^{2}$ en 1531-2), la escasez de la cubierta arbórea ha podido incidir en la población de lobos en función tanto de las posibilidades de refugio como de la alimentación de los herbívoros.

Esta incursión por las diversas aldeas de Trujillo y Cáceres nos permiten esbozar algunas ideas. El lobo ocupaba los diversos territorios, pero era más abundante en los lugares menos humanizados y con más cubierta vegetal, en donde los grandes herbívoros podían proliferar más fácilmente. Esto explica su mayor abundancia en las zonas serranas, mientras en la penillanura quizás presente una tendencia a un tímido receso. Asimismo, sería sensible a un cambio brusco del medio natural, como parece detectarse en Garciaz y Berzocana.

En todo caso, los lobos serían mas numerosos a finales de la Edad Media y principios de la Moderna que en épocas posteriores. En algunas poblaciones como Aliseda o Sierra de Fuentes pasan de ser bastante abundantes hacia el 1500 a casi desaparecer a finales del XVIII ${ }^{173}$. En Garciaz podemos hacer una comparación rudimentaria. En 1506 se cazan cinco camadas y en 1507 , dos camadas y se realiza un libramiento referido a lobos en general; a finales del XVIII se estima en cuatro el número de lobos cazados anualmente. Las cantidades referidas a 1506 y 1507 son mínimas, pues en muchos casos no se precisa la vecindad de la persona que recibe la recompensa; además, en el siglo XVIII la caza es más sistemáti$\mathrm{ca}^{174}$. Las recompensas pagadas por la captura de lobos se satisfacen

\footnotetext{
${ }^{173} \mathrm{G}$. BARrientos y M. Rodríguez, Ibid., p. 11; en Sierra de Fuentes no se mencionan.

${ }^{174} \mathrm{AMT}$, leg. 8.24 , fols. $14 \mathrm{r} 14 \mathrm{v}, 29 \mathrm{r}$ y $38 \mathrm{r}$; G. BARRIEnTOS y M. RODRíGUEz, Interrogario... Partido de Trujillo, I, p. 697.
} 
mayoritariamente a personas que, a diferencia de los ballesteros y loberos, no realizan esta labor de modo profesional, lo que muestra la proximidad espacial entre estos animales y el hombre a finales del XV y principios del XVI.

En cualquier caso, el receso que se produce entre la Baja Edad Media y finales de la Edad Moderna debio ser extremadamente lento. Lo que parece evidente es que entre 1490 y 1520 el número de lobos se debió mantener estable. En Cáceres, el monto de las recompensas y el número de libramientos oscilan sin que haya una tendencia clara. En cuanto a Trujillo, entre 1505 y 1512 , son más elevados en los años finales (cf. cuadros 1 y 2). Los lobos parecen encajar perfectamente el conflicto que les enfrenta al hombre, lo que nos permite suponer que como mínimo su número triplicaría holgadamente el número de capturas ${ }^{175}$.

${ }^{175} \mathrm{Se}$ ha estimado que la población de lobos tiende a disminuir cuando las capturas invernales superan el $38 \%$ de los efectivos existentes en otoño (A. Clevenger y F. PURROY, Ibid., p 134). 


\section{Lobos: Capturas y Recompensas}

Cuadro I: Alfoz de Cáceres

(Fuente: AMC, Cuentas de Propios)

\begin{tabular}{llllllll}
$\frac{\text { Año }}{1496}$ & $\frac{\text { Lb. }}{2}$ & $\frac{\text { Cam }}{3}$ & $\frac{\text { Mrs. }}{650}$ & $\frac{\text { Libr. }}{5}$ & $\frac{\text { Año }}{1510}$ & $\frac{\text { Mrs. }}{1.850}$ & $\frac{\text { Libr. }}{12}$ \\
1498 & $* 8$ & 4 & 1.475 & 10 & 1511 & 1.900 & 14 \\
1501 & 18 & 4 & 2.400 & 19 & 1512 & 3.650 & 28 \\
1502 & 6 & 5 & 1.350 & 10 & 1513 & 2.450 & 19 \\
1503 & 21 & 4 & 2.700 & 23 & 1514 & 2.140 & 14 \\
1505 & & & 1.650 & 13 & 1515 & 2.850 & 21 \\
1506 & & & 3.650 & 29 & 1516 & 2.250 & 16 \\
1507 & & & 2.050 & 15 & 1517 & 1.550 & 10 \\
1508 & & & 2.700 & - & 1518 & 1.550 & 13 \\
1509 & 950 & 8 & 1519 & 1.650 & 9 \\
\multicolumn{5}{c}{ * se cazan también "unos lobillos" }
\end{tabular}

Cuadro 2: Alfoz de Trujillo

(Fuente: AMT, leg. 8.24)

\begin{tabular}{|c|c|c|c|c|}
\hline$\underline{\text { Año }}$ & $\underline{L b}$ & Cam & Lib. & Mrs. \\
\hline 1505 & 38 & 12 & 44 & 6.020 \\
\hline 1506 & 15 & 19 & 20 & 4.540 \\
\hline 1507 & 12 & 6 & $14 *$ & 2.400 \\
\hline 1508 & $* *$ & & 44 & 5.528 \\
\hline 1509 & & & 38 & 6.264 \\
\hline 1510 & & & 47 & 7.600 \\
\hline 151 & & & & 7.000 \\
\hline & & & & 6.000 \\
\hline
\end{tabular}

*dos de ellos de lobos a secas

** se computan, por un lado, 163 lobos (seguramente se cuentan tanto lobeznos como lobos adultos) y, por otro, 12 lobos en 9 libramientos

$\mathrm{Lb}=$ lobos $\quad \mathrm{Cam}=:$ Camadas $\quad$ Mrs $=$ Maravedís Lib $=$ Libramientos 


\subsection{Herbivoros y ornitofauna}

La fauna herbívora aparece citada en cuanto fuente de alimentación. Las distintas referencias adolecen de repetitivas. Muchas de ellas aparecen en las ordenanzas, que no permiten una aproximación cuantitativa. Algunas informaciones aisladas y dispersas nos posibilitan trascender un modelo genérico que aparece con gran claridad y que va a mantenerse durante varios siglos.

Los animales que aparecen citados, es decir, aquéllos que ofrecen mayor interés cinegético, están en gran medida en conexión con el ecosistema de la dehesa; algunos pueden desarrollarse en espacios altamente humanizados. La grandes herbívoros están representados por el venado, termino que a veces designa a la caza mayor en general, y el jabalí; sobre los demás ungulados salvajes solo podemos citar una referencia indirecta a los gamos ${ }^{176}$; sobre los corzos el silencio es total ${ }^{177}$. Los pequeños herbívoros están representados fundamentalmente por liebres y conejos y las aves, por la perdiz, la paloma y, en menor medida, por los ansares. Nada se nos dice de las avutardas ${ }^{178}$. Las referencias a otra caza menuda nos indica la existencia de una fauna más variada ${ }^{179}$. No se mencionan las aves de presa

\footnotetext{
176." Ios carniçeros y ballesteros y otras perssonas algunas no sean osadas de sacar las coranbres vacunas, cabrunas, ni de carneros, ni çervunas, ni gamuñas cortidas o por curtir de la villa o de los lugares y aldeas de su jurediçion para las llevar a vender a fuera parte" (BOHÓRQUEZ, Ibíd., p. 196).

${ }^{177}$ Este animal tiene unas exigencias ecológicas mas rigurosas que el ciervo; adaptado al bosque bajo denso, las transformaciones que desde las primeras décadas del siglo XV sufrió el paisaje vegetal debieron condicionarle negativamente. Se documenta ampliamente, sin embargo, en el siglo XVIII (M. TERRÓN AlBARRÁN, lbíd., pp. 69-70).

${ }^{178}$ Sus exigencias ecológicas no son las más adecuadas para una zona donde la agricultura tradicional cede ante el empuje de la explotación ganadera de la dehesa (cf. S.H. HIDALGO DE Trucios y J. Carranza Almansa, Ecología y comportamiento de la avutarda, Cáceres, 1990, pp. 123-30).

${ }^{179}$ Veamos algunas de las referencias más ilustrativas: en el acuerdo de vecindad entre Cáceres y Mérida de 1493 se alude a "caçar liebres, o conejos, o perdizes o palomas o otra caça menuda" y a "montear o ballestear venados o puercos"; se puede sacar de un termino a otro "dos pares de ansarones"; con la excepción de éstos últimos, se mencionan las mismas especies en el acuerdo de vecindad entre Cáceres y Badajoz de 1501 (GARCía Oliva, Documentación, docs. 117 y 195); en la Ordenanza del valor de la caza de 1509 de Trujilo se indica que en sus montes "se crian asy de perdizes e palomas como de liebres e conejos e venados" (SÁNCHEZ RUBIO, Documentación, III, p. 151); en las Ordenanzas de Valencia de Alcántara se alude a la "caça de liebres, perdizes o conejos o palomas" y a la prohibición de sacar pieles "ni çervunas ni gamuñas" (BOHÓRQUEZ, Ibíd., 208 y 196).
} 
ni los carroñeros ${ }^{180}$. Como no suponen un peligro apreciable para la ganadería y no inciden de modo sensible sobre las poblaciones de aves y pequeños herbívoros no encuentran lugar en las ordenanzas. La toponimia, sin embargo, nos informa de la existencia suficientemente representativa de rapaces y buitres ${ }^{181}$.

Pese a las características de la información, parece necesario responder a algunos interrogantes que nos aproximen al estado real de la fauna salvaje en la Baja Edad Media y comienzos de la época moderna. Un rasgo parece claro, la humanización creciente del paisaje y el crecimiento demográfico presionaron de tal manera sobre la fauna salvaje que se convirtió en una necesidad proteger a las especies de interés cinegético ${ }^{182}$. Solo documentamos una prohibición que merece el calificativo de antigua $^{183}$ y que nos hace pensar que en torno a los centros de población más importantes estas especies empezaron a escasear cuando aún eran relativamente abundantes en espacios más alejados. En Cáceres, donde se prohibe cazar liebres o perdices en dos leguas alrededor de la villa, esto no ofrece dudas. Pero no parece raro que, aunque no nos consten prohibiciones de este tipo en otros lugares, esta realidad se repitiera con más o menos fuerza. En Trujillo, el paisaje del berrocal, con un escaso estrato arbóreo, sólo favorecería a algunas especies animales. De hecho, alguna alusión al conejo y la toponimia parecen señalar que sería la asociación conejo/aguila la dominante; el insuficiente arbolado incidiría negativamente en otras especies

\footnotetext{
${ }^{180}$ En Plasencia se recompensa la captura de águilas: la normativa aparece en sus ordenanzas (Bibl. Publ. Cáceres, Mss. 35, fol. 452 v); se satisfacen diversas cantidades por este concepto en las cuentas municipales de 1507-1509 (AMP), aunque ninguna corresponde a lugares situados al sur del Tajo.

${ }^{181}$ En el conflicto de terminos entre Arroyo del Puerco y Cáceres de 1436 se alude a una Peña del Buitre (FloRIANO, Ibíd., doc. 86); en el término de Garciaz aparece la heredad de La Buitrera (AMT, leg. 3, $\mathrm{n}^{\circ} 1$, fol. $142 \mathrm{v}$.; leg. 1, $\mathrm{n}^{\circ} 1$, fol. 7 v.); hay una Dehesa de la Rapaza en tierras alcantarinas (AHN, Mesta, caja 39, $\mathrm{n}^{\circ}$ 7) y una Peña del Aguila en el berrocal trujillano (AMT, leg. 3, n ${ }^{\circ}$, fol. 391 r.).

${ }^{182}$ Es un fenómeno bastante extendido en la Corona de Castilla: $M^{\mathrm{a}}$ ASENJo GonZÁlez, Segovia. La ciudad y su tierra a fines del medievo, Segovia, 1986, pp. 182-183; A. BERNAL ESTÉVEZ, El concejo de Ciudad Rodrigo y su tierra durante el siglo XV. Salamanca, 1989, pp. 328-31; E.C. DE SanTos CANALEJo, Ibid., pp. 405-8; M.A. Ladero QueSAda, La caza en las ordenanzas municipales de Andalucía. Siglos XV y XVI, "La Chasse au Moyen Age". Niza, 1980, p. 240-7; D. MENJot, Les murcians du Bas Moyen Age a la chasse, "Ibid.", p. 261.

${ }^{183}$ En 1492 el corregidor Diego Ruiz de Montalvo, corregidor de Cáceres, falla contra las nuevas normas de protección de árboles, caza y pesca, porque "sacando la caça de las liebres e perdizes para bolar las aves que antiguamente solian usar e proybir dos leguas en derredor, ser todo nuevamente ynpuesto" (GARCía Oliva, Documentación, doc. 106).
} 
como la perdiz. Todo hace pensar que el paisaje vegetal unido a la existencia de una importante población en su centro haría del berrocal un espacio que, al igual que los alrededores de Cáceres, presentaría una pobre fauna salvaje.

Al margen del empobrecimiento de la fauna en los espacios que rodean a las más importantes poblaciones, las normativas, que proliferan con gran homogeneidad, tienen un carácter general y afectan al conjunto de los alfoces. Sobre la cronología de este proceso podría argüirse que las ordenanzas pudieron poner por escrito usos más antiguos. Así sería en muchos casos, pero la generalización de las prohibiciones sobre la actividad cinegética a partir de las últimas décadas del siglo XV parece indicar que son usos relativamente recientes que han surgido para responder a las consecuencias del crecimiento demográfico y la subsiguiente presión sobre los recursos. El caso cacereño nos presenta esta realidad de modo transparente. En 1492, el procurador de la tierra Gonzalo Martínez Espadero protestó porque los regidores vedaban la caza "de los montes bravos e xarales, e la pesca de los ríos"; los regidores contestarán que solamente "haziades como hazían en todas las otras çibdades e villas e lugares de nuestros reynos, que es vedarse los meses que crían e que no caçen con recobo e con otras artes semejantes, porque sy a lo tal se diese lugar sería dar causa que un mes talasen toda la caça" ${ }^{184}$. Ese mismo año, el corregidor Diego Ruiz de Montalvo pronuncia una sentencia en el conflicto que mantienen las aldeas contra la villa sobre aprovechamientos comunales en la que se indica como "de poco tienpo a esta parte, contra el tenor e forma de la ley del fuero, e sus usos e costumbres antiguos... acotan e an acotado la lenna seca de la Çafrilla... acotando asy mesmo la caça e pesca de los rios"185. El corregidor falla en contra de las nuevas normativas, exceptuando la ya citada que prohibía cazar liebres o perdices en dos leguas alrededor de Cáceres. Pese a todo esto, en 1494 se redactan las ordenanzas de la caza, que definen un panorama proteccionista que parece responder a una necesidad y en donde se recogen toda una serie de normativas que antes han generado oposición.

Para otros alfoces no tenemos detalles tan concretos. Sin embargo, no cabe duda de que las ordenanzas de Valencia de Alcántara o Trujillo muestran un modelo proteccionista muy similar y unas coordenadas cronológicas coincidentes.

\footnotetext{
${ }^{184}$ García Oliva, Documentación, doc. 92.

${ }^{185}$ García Oliva, Documentación. doc. 106.
} 
Es llamativo que las normas de protección afecten exclusivamente a la caza menor de conejos, liebres, perdices o palomas. Es posible que este detalle se deba a una separación clara entre caza mayor, más elitista y profesionalizada, y caza menor, practicada por amplios sectores de la población. En realidad la caza se practicaba con muy diversos medios y las fronteras eran permeables. Algunos, denominados ballesteros, se dedicarían profesionalmente a la caza de grandes herbívoros y $\operatorname{lobos}^{186}$. Sin embargo, también realizaban esta actividad personas no especializadas. En los acuerdos de vecindad entre Badajoz y Cáceres se señala a "qualquier persona o personas" como posibles cazadores de venados y jabalíes ${ }^{187}$. En cualquier caso, sería desigual la presión ejercida sobre la caza mayor y la menor. De hecho, las normas proteccionistas, como hemos señalado, sólo afecten a esta última, mucho más generalizada y más fácil de desarrollar y, por tanto, más amenazada. La ballesta, utilizada en la primera, parece menos mortífera que las diversas trampas utilizadas para liebres, conejos o perdices. Esto explica que este instrumento se incluya entre las artes permitidas.

La fauna en general mantiene distintas densidades. Alrededor de las villas es claramente menos abundante. Cáceres nos ofrece el ejemplo ideal a traves de la ordenanza de la caza. Un espacio de dos leguas alrededor de la villa requiere una protección especial. Esta protección es ya vieja a finales del siglo XV. En Trujillo, palomas y perdices tienen un precio distinto en la villa y las aldeas ${ }^{188}$.

Esta circunstancia no impide que algunos animales, como los conejos, sean abundantes en las proximidades de las mayores aglomeraciones humanas. No se incluyen entre las especies protegidas alrededor de Cáceres. En el berrocal trujillano aparecen citados dos "forados" de conejos cercanos a la Aldehuela de Sancho Blázquez y las casas de Torre Aguda. En Valencia de Alcántara proliferan en las viñas mal atendidas junto a los zorros. En Brozas, con un número de vecinos pecheros superior al de Trujillo hacia

\footnotetext{
${ }^{186}$ Las Ordenanzas de Valencia de Alcántara reglamentan que "los vallesteros de monte ussen de sus ofiçios y que todos los venados y reses de monte que mataren no las pessen ni vendan hasta que primero sean vistas por los fieles" y que "carneçeros y ballesteros y otras personas algunas no sean osadas de sacar las coranbres vacunas, cabrunas, ni de carneros, ni çervunas. ni gamuñas cortidas o por curtir de la villa o de los lugares y aldeas de su jurediçion" (BOHÓRQUEZ, Ibid., pp. 195-196).

${ }^{187}$ García Oliva, Documentación, doc. 195, rub. 10; se documenta algún caso de restricción del derecho de caza en favor de los grupos privilegiados (D. MENJot, Ibid., pp. 261-2).

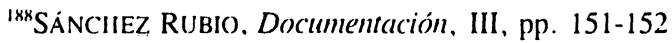


1530 y próximo al de Cáceres o Alcántara, aparece un "altozano conejil" junto al ejido de la aldea y cerca de los huertos ${ }^{189}$. Sin duda, estos animales tienen a su favor su carácter prolífico y su adaptación a terrenos muy deforestados.

Los terrenos más alejados de las villas y centros de población, especialmente los montuosos, en los que el estrato vegetal era abundante, cuentan con una fauna salvaje más abundante que permite una más lucrativa actividad cinegética. Dentro del término cacereño, muchas de las prohibiciones generales no tienen validez en la Sierra de San Pedro. Aquí sólo estaba vedado el uso de la cuerda de alambre; además podían cogerse los huevos de perdices y cazarse los perdigones chicos. En Trujillo, la caza aparece vinculada al monte y los conejos parecen especialmente abundantes en "xarales e montes" 190 .

El papel económico de la caza no sería despreciable, pero distaba de ser una actividad fundamental. Tanto la caza mayor como la menor alimentaban simultáneamente el autoconsumo y la actividad comercial. Este papel en cierta medida subsidiario de la caza se manifiesta en que algunos productos cinegéticos, a juzgar por el carácter suntuario que adquieren en las navidades ${ }^{191}$, no serían de consumo habitual.

Pese a todo, y aunque se hacía necesario el control de las artes más mortíferas, la fauna salvaje debía ser aún bastante abundante, al menos con los parámetros actuales. Aparecen actividades especializadas que sólo una relativa abundancia pueden explicar. En Trujillo se documenta a Hernando Sánchez, conejero de Garcíaz. Se alude también a perdigueros y a un guarda de las liebres. En un censo de 1505 se entrega un par de pérdices ${ }^{192}$.

En el término de Cáceres, las palomas parecen ser especialmente abundantes. Palomeros de otras poblaciones obtienen permiso casi todos los

\footnotetext{
${ }^{1 \times 9}$ García Oliva, Documentación, doc. 126; AMT, leg. 1, $\mathrm{n}^{0} 1$, fols. 96 r.-97 v.; BOHÓRQUEZ, Ibid., p. 118; AHN, Mesta, caja 39, n 7 .

${ }^{1 \% 1}$ García Oliva, Documentación, doc. 126, p. 250; SÁnciez Rubio, Documentación, III, p. 151 ("esta çibdad de Trogillo es proveyda de muchas cosas, espeçialmente de caça, porque en los montes della abundantemente se crian asy de perdizes e palomas como de liebres e concejos e venados") y 135 .

${ }^{19 !}$ En Valencia de Alcántara, el precio de las perdices sube un $25 \%$ en estas fechas y el de las palomas hasta un $40 \%$; los conejos mantienen, sin embargo, su precio a lo largo de todo el año (BOHÓRQuEZ, Ibíd., p. 209).

${ }^{192}$ AMT, leg. $3, \mathrm{n}^{\text {0 }} 1$, fols. 137 r. y 138 v.; leg. 8, n 24 , fols. 184 r. y 187 v.; SÁNCHEZ RUBIO, Documentación, II, docs. 204 y 272.
} 
años para cazarlas pagando un número variable de pares. En 1502 entregan doscientos y en 1503, doscientos noventa. Entre 1506 y 1515 la cantidad disminuye para situarse entre ciento cincuenta y siete en 1512 y veintisiete en 1510, cifra excepcionalmente baja que no parece tener una fácil explicación. No parecen disminuir, pues en 1516 el concejo recibe doscientos ochenta pares y en 1518, 3.326 maravedís (en 1516, cada par tiene un valor de 8 maravedís $)^{193}$.

\subsection{El medio acuático}

El medio acuático está sujeto a una creciente explotación que se hace necesario controlar. En el conflicto ya citado que opone en 1492 al común y a las autoridades de la tierra de Cáceres se menciona el agotamiento no sólo de la caza sino también de la pesca. En esta realidad debió jugar un papel importante la utilización de diversas hierbas (torvisca, gordolobo) para el envenenamiento de las aguas, práctica sistemáticamente prohibida. Se detecta un interés en la protección de los peces pequeño. Los concejos dan normas sobre las redes para que el "pescado menudo" no quede afectado $^{194}$.

La riqueza pesquera se ve favorecida por unos cursos de agua posiblemente más regulares que los actuales. La existencia de un manto vegetal que, pese a la agresión que está sufriendo, debía ser aún bastante importante y el predominio de un tiempo lluvioso y con escasas sequías a lo largo del siglo XV debieron producir estiajes menos acusados. El río Sever se presenta como "rio natural y corriente todo el año"; en Trujillo, en agosto "las aguas son menguadas"; la Ribera de David, en Valencia de Alcántara, dejaba de correr en Junio ${ }^{195}$.

Estas circunstancias debieron condicionar positivamente a la fauna acuática. Las modestas corrientes de agua de la margen izquierda del Tajo se explotan sistemáticamente. No sólo se práctica la pesca en los ríos

\footnotetext{
${ }^{193}$ García Oliva, Documentación, docs. 211 y 220; AMC, cuentas de propios de 1506 , $1509,1510,1511,1512,1513,1515,1516,1518$ y 1519.

${ }^{194}$ BoHÓRQUEZ, Ibíd., pp. 175 y 254; GARCía Oliva, Documentación, docs. 51, 92 y 122; SÁNCHEZ RUBIO, Documentación, III, p. 29.

${ }^{195}$ I. FONT TULLOT, Historia del clima de España. Cambios climáticos y sus causas, Madrid, 1988, pp. 66-3; BOHÓRQUEZ, Ibíd., pp. 182 y 186; SÁNCHEZ RUBIO, Documentación, III, pp 105 y 172. Sobre el régimen y estiajes de los afluentes de la margen izquierda del Tajo, L. GARCIA GONZÁLEZ, Los ríos extremeños. Introducción a su régimen, Badajoz, 1994, pp. 69-70.
} 
principales sino también en los arroyos. En los lugares proximos al Tajo, este río se convierte en campo preferente de la actividad pesquera. En Alcántara, el pescado fresco esta sujeto al diezmo, lo que muestra una relativa importancia ${ }^{196}$. Pero, incluso en Trujillo, que no cuenta con corrientes de agua equiparables, algunas personas se catalogan como "pescador atentico... asy de invierno como de verano e de agosto" ${ }^{197}$.

La información sobre las especies es muy limitada. Junto a especies migratorias como sábalos y anguilas, se pescaban especies autóctocnas como los barbos. Es muy llamativo que se mencionen truchas, especie que prefiere las aguas limpias y oxigenadas de las gargantas, en Valencia de Alcántara, lo que quizás sea debido a la mayor regularidad de los caudales.

\section{CONCLUSIONES}

A finales de la Edad Media, el crecimiento de la población y la creciente presión sobre los recursos en la vertiente meridional del Tajo extremeño van a generar una problemática nueva en relación con el medio natural. Frente a la situación anterior, caracterizada por una escasa regulación y por la existencia de concesiones reales y normas concejiles poco limitativas, en la Baja Edad Media el desarrollo de las ordenanzas municipales viene a responder a una nueva situación. La necesidad de controlar tanto los aprovechamientos silvícolas como la caza o la pesca se convierte en algo perentorio.

Una manifestación de las contradicciones que afectan a esta sociedad es la generalización de la lucha contra el lobo, lo que hay que entender como una manifestación de los desequilibrios existentes. Los ataques que sufrió la cubierta vegetal y la presión creciente sobre la caza debió afectar a los grandes herbívoros. La disminución de sus víctimas potenciales junto a la existencia de una abundante ganadería trashumante y estante convirtió la lucha contra este cánido en una necesidad. El ganado doméstico debió cumplir en la estación invernal una función de sustitución respecto de venados, corzos o jabalíes.

\footnotetext{
${ }^{196}$ A. DE TORRES Y TAPIA, Ibid., I, p. 539, II, pp. 269 y 367.

${ }^{197}$ SÁNCHEZ RUBIO, Documentación, III, p. 187.
} 
El medio natural se caracteriza a finales de la Edad Media por la profunda influencia que ejerce la actividad humana en los paisajes vegetales y por el desarrollo de unas normas restrictivas en las prácticas silvícolas, cinegéticas y pesqueras. En relación con el primer aspecto, hay dos características de la mayor importancia: la tala selectiva de especies arbóreas, lo que disminuyó considerablemente la variedad específica, y el desarrollo de formas de degradación, de las que los jarales son la manifestación más importante. Se favorece a las quercíneas y en especial a la encina, susceptibles de una explotación tanto maderera como pecuaria, dentro de un espacio adehesado que, fuera de los espacios agrarios, se convierte en omnipresente.

En relación con el segundo aspecto, se intentará que la obtención de madera no afecte a la riqueza forestal. La tala va a requerir un permiso y será el corte de ramas el medio más frecuente de obtener leña o madera. Las sucesivas podas, necesarias para favorecer la producción de bellotas, se van a convertir en una fuente importante para la obtención de recursos silvícolas. En el ambito de la caza o la pesca, el panorama viene definido por la prohibición de los ingenios más efectivos o las prácticas más indiscriminadas y el desarrollo de normas especiales que intentan posibilitar el mantenimiento o recuperación de la riqueza cinegética y pesquera. De este modo, se protege a las especies en la época de cría a la vez que se prohibe el envenenamiento de las aguas.

La sociedad bajomedieval responde a la creciente presión sobre los recursos naturales intentando la obtención de un equilibrio como medio de permitir un modelo autosostenido. La huella de las actividades humanas es profunda y pocas cosas escapan a su influencia.

\section{RÉSUMÉ}

Durant le bas Moyen Âge, la croissance de la population et la pression constante exercée sur les ressources naturelles se sont traduites par de nouvelles habitudes vis-à-vis de l'environnement sur le versant méridional du Tajo. La présence de l'homme semble être un facteur décisif pour expliquer la végétation. Ainsi, l'action de celui-ci n'est pas étrangère á l'extension des forêts de chênes (dehesas), ou aux formes de dégradation qui se reflètent avant tout les lieux plantés de cistes. Les ordannaces du bas Moyen Âge dessinent très clairement ce nouveau paysage. Elles imposent un contrôle sévère de la richesse arborée afin que l'approvisionnement en bois (de chauffage et de construction) puissse aller de pair avec le maintien d'un nombre suffisant d'arbres qui offrent les glands et les branchages indispensables 
au bétail. Parallèlement, on commence à interdire ou à limiter à certaines périodes de l'année la pêche et la chasse. Tant la progressive disparition de l'ours, animal à caractère forestier, que la chasse au loup tèmoignent de haut degré de civilisation du paysage, qui a aussi eu des conséquences sur la faune sauvage hervibore.

\section{SUMMARY}

The growth of population and the increasing pressure on natural resources during the Late Middle Ages would demand a new attitude towards the natural environment of the land south of the Tagus River. Man becomes thus the prime conditioning factor to explain the vegetation of the landscape. His actions are not unrelated to the spreading of the holm oak dehesa and to those forms of degradation whose most outstanding manifestation can be found in the areas overgrown with rockroses. Late medieval ordinances clearly define this new reality. There was to be a strict control of the woodland; thus the supply of timber and firewood was hinged upon the preservation of those trees which provide acorns and twigs for fodder, indispensable for livestock breeding. Furthermore, bans and close seasons were introduced to protect hunting and fishing. Both the dwindling number of bears, an animal akin to the forest, and the war waged against the wolf, are a clear expression of man's impact upon the landscape which must have greatly affected the herbivorous wildlife. 